\title{
Atmospheric processes of organic pollutants over a remote lake on the central Tibetan Plateau: implications for regional cycling
}

\author{
Jiao Ren ${ }^{1,3}$, Xiaoping Wang ${ }^{1,2}$, Chuanfei Wang ${ }^{1,2}$, Ping Gong ${ }^{1,2}$, and Tandong Yao ${ }^{1,2}$ \\ ${ }^{1}$ Key Laboratory of Tibetan Environment Changes and Land Surface Processes, Institute of Tibetan Plateau Research, \\ Chinese Academy of Sciences, Beijing, 100101, China \\ ${ }^{2}$ CAS Center for Excellence in Tibetan Plateau Earth Sciences, Beijing, 100101, China \\ ${ }^{3}$ University of Chinese Academy of Sciences, Beijing 100049, China \\ Correspondence to: Xiaoping Wang (wangxp@itpcas.ac.cn)
}

Received: 8 November 2016 - Published in Atmos. Chem. Phys. Discuss.: 16 November 2016

Revised: 13 January 2017 - Accepted: 13 January 2017 - Published: 31 January 2017

\begin{abstract}
Atmospheric processes (air-surface exchange, and atmospheric deposition and degradation) are crucial for understanding the global cycling and fate of organic pollutants (OPs). However, such assessments over the Tibetan Plateau (TP) remain uncertain. More than $50 \%$ of Chinese lakes are located on the TP, which exerts a remarkable influence on the regional water, energy, and chemical cycling. In this study, air and water samples were simultaneously collected in Nam Co, a large lake on the TP, to test whether the lake is a secondary source or sink of OPs. Lower concentrations of organochlorine pesticides (OCPs) and polychlorinated biphenyls (PCBs) were observed in the atmosphere and lake water of Nam Co, while the levels of polycyclic aromatic hydrocarbons (PAHs) were relatively higher. Results of fugacity ratios and chiral signatures both suggest that the lake acted as the net sink of atmospheric hexachlorocyclohexanes $(\mathrm{HCHs})$, following their long-range transport driven by the Indian monsoon. Different behaviours were observed in the PAHs, which primarily originated from local biomass burning. Acenaphthylene, acenaphthene, and fluorene showed volatilization from the lake to the atmosphere, while other PAHs were deposited into the lake due to the integrated deposition process (wet/dry and air-water gas deposition) and limited atmospheric degradation. As the dominant PAH compound, phenanthrene exhibited a seasonal reversal of air-water gas exchange, which was likely related to the melting of the lake ice in May. The annual input of HCHs from the air to the entire lake area $\left(2015 \mathrm{~km}^{2}\right)$ was estimated as $1.9 \mathrm{~kg} \mathrm{yr}^{-1}$, while input estimated for $\sum_{15}$ PAHs can potentially reach up to $550 \mathrm{~kg} \mathrm{yr}^{-1}$. This study highlights the
\end{abstract}

significance of PAH deposition on the regional carbon cycling in the oligotrophic lakes of the TP.

\section{Introduction}

Since the previous century, large quantities of organic pollutants (OPs), such as organochlorine pesticides (OCPs), polychlorinated biphenyls (PCBs), and polycyclic aromatic hydrocarbons (PAHs), have been discharged into the global environment. Soils, water bodies, and snow/ice are generally considered to be reservoirs or sinks of these pollutants (Dalla Valle et al., 2005; Froescheis et al., 2000; Guglielmo et al., 2012). However, due to the influence of global warming (Komprda et al., 2013; Noyes et al., 2009), growing evidence indicates that OPs previously stored in reservoirs can be rereleased back into the environment (Ma et al., 2011). For example, air-soil exchange of OCPs has showed the reemission of OCPs from previously contaminated soils in Europe (Ruzickova et al., 2008), North America (Kurt-Karakus et al., 2006), and India (Chakraborty et al., 2015). Modelling results have suggested that large parts of the global ocean have been losing dichlorodiphenyltrichloroethane (DDT) via volatilization (Stemmler and Lammel, 2009). In addition, air-sea exchange of PAHs has revealed that the seawater in the Mediterranean has turned into a temporary secondary source of PAHs, which is related to biomass burning in that region (Mulder et al., 2014). Moreover, melting ice and glaciers have also released OPs back into the atmosphere, 
which buffers the decline of OP levels in the polar regions (Ma et al., 2011; Geisz et al., 2008).

Similarly to the polar regions, the Tibetan Plateau (TP) has been regarded as a convergence zone of OPs (Wang et al., 2016). Due to the continuous use of OPs in the surrounding countries and the "cold trapping" by the TP, the enrichment of OPs in the TP environment has been reported (Sheng et al., 2013; Wang et al., 2015). However, the TP has experienced significant warming (Liu and Chen, 2000), and results of the air-soil exchange of OPs have indicated that the Tibetan soils are acting as a sink of DDT and higher molecular weight PAHs, but are a potential secondary source for hexachlorobenzene (HCB) and hexachlorocyclohexanes (HCHs) (C. F. Wang et al., 2014; X. P. Wang et al., 2012). This shows that the cold temperature over the TP might not be sufficient to trap volatile OPs. More studies on the air-surface exchange of OPs over the TP are therefore needed to test the role of the terrestrial and aquatic ecosystems of the TP in the regional cycling of OPs.

Known as "Asia's water power", the TP contains the headwaters of many major rivers in Asia, which provide water sources for about one-sixth of the world's population (Yao et al., 2012). The TP also has large numbers of remote lakes that are important components of water bodies. Low temperature, oligotrophic conditions, and the long duration of ice cover are distinct features of these lakes. Based on the higher atmospheric concentrations of $\alpha-\mathrm{HCH}$ in summer, Xiao et al. (2010) deduced that these enhanced concentrations may be caused by the thawing of lake ice, which promotes the reevaporation of $\alpha-\mathrm{HCH}$. However, the study did not include measurements of $\mathrm{HCH}$ levels in lake water or the corresponding air-water exchange analysis (Xiao et al., 2010). Therefore, it is still unclear whether the lake water of the TP is the secondary source of a large number of OPs. Furthermore, biomass burning is a widespread activity over the TP (Hu et al., 2015). A recent study demonstrated that the locally sourced biomass combustion particles contributed substantially to the black carbon (BC) loading of the TP glacier (Li et al., 2016). Given that PAHs and BC both mainly originate from incomplete combustion of biomass, regional air-water exchange of PAHs would also contribute to the overall airsurface exchange of carbon.

We therefore conducted air and water sampling in a remote lake on the TP, and assessed the air-water gas exchange, and the dry and wet deposition processes of OCPs, PCBs, and PAHs. The aims of this study were to ascertain whether the Tibetan lake represents a secondary source of OPs, to investigate the influence of seasonal lake ice melting on the gas exchange of different OPs, and to estimate the contribution of PAH exchange to the lake carbon budget.

\section{Materials and methods}

\subsection{Site description}

Nam Co lake $\left(30^{\circ} 30^{\prime}-30^{\circ} 56^{\prime} \mathrm{N}, 90^{\circ} 16^{\prime}-91^{\circ} 01^{\prime} \mathrm{E}, 4718 \mathrm{~m}\right)$ is located in the north of the Nyainqêntanglha Mountains, on the central TP (Fig. 1). It is the second largest lake in Tibet with an area of $2015 \mathrm{~km}^{2}$ and a maximum depth exceeding $90 \mathrm{~m}$ (Wang et al., 2009). The lake is mainly supplied by precipitation and glacier meltwater. Annual riverine delivery of water to the lake is approximately $1.3 \times 10^{9} \mathrm{~m}^{3} \mathrm{yr}^{-1}$, while there is no outflow (Wu et al., 2014). The lake water is alkaline $(\mathrm{pH}=9.21)$ and slightly saline (Wang et al., 2009). The climate of Nam Co is relatively cold and windy with an annual average temperature of $\sim 0^{\circ} \mathrm{C}$ and an annual wind speed of $\sim 4 \mathrm{~m} \mathrm{~s}^{-1}$. The regional climate also has large seasonal variation: the Indian monsoon dominates in summer (May to September) and the westerlies the control winter climate (October to April) (Fig. S1 in the Supplement). High temperatures and precipitation are usually observed in summer (Fig. S2), and the lake begins to thaw from the beginning of May and melts completely by the end of May, which coincides with the onset of the Indian monsoon. During the winter, the lake is covered by ice due to the subzero temperatures (Fig. S2) and maximum instantaneous wind speeds reaching up to $9.9 \mathrm{~m} \mathrm{~s}^{-1}$.

The dominant land cover in Nam Co is alpine steppe and meadow, and the local residents herd yak and sheep that graze around the lake. Biomass burning occurs for heating, cooking, transport, and religious reasons. Near the southeastern shore, the Nam Co Monitoring and Research Station for Multisphere Interactions (NCMORS) is operated by the Chinese Academy of Sciences (Fig. 1b). This station not only facilitates the consecutive collection of field samples used in the current study, but also provides local meteorological parameters for flux calculations.

\subsection{Air and water sampling}

An active air sampler (AAS) was deployed on the roof of NCMORS (Fig. 1b) and air monitoring was conducted for 2 consecutive years from September 2012 to September 2014. The flow rate of AAS was $60 \mathrm{~L} \mathrm{~min}^{-1}$ and the air samples were collected every 2 weeks with a volume of approximately $600 \mathrm{~m}^{3}$ for each sample. The airstream first passes through glass fibre filters (GFFs $0.45 \mu \mathrm{m}$, Whatman) to collect the total suspended particles (TSP) and then through polyurethane foam (PUF, $7.5 \times 6 \mathrm{~cm}$ diameter) to retain the OPs in gas phase. In total, 47 air samples were collected. Details regarding the sampling period, average air temperature, and wind speed are given in Table S1 in the Supplement. All harvested PUF and GFFs were stored at $-20^{\circ} \mathrm{C}$ until extraction.

To determine the OP levels in water, two sampling programmes were conducted. First, 15 sites around the Nam Co 

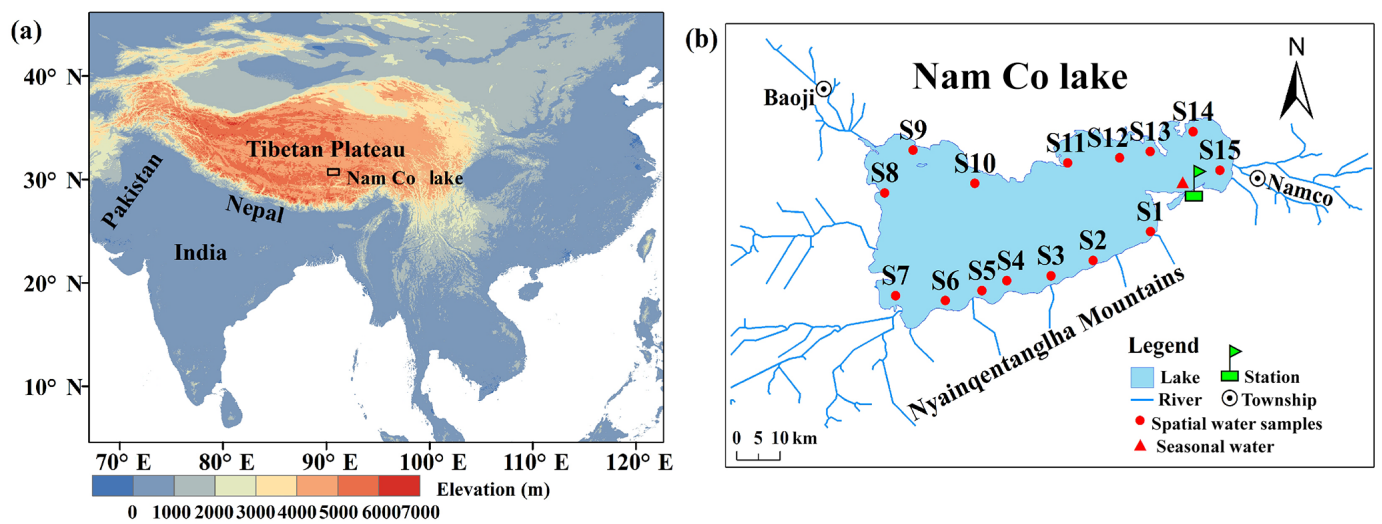

Figure 1. Location of Nam Co lake on the Tibetan Plateau (a) and the sampling sites for air and lake water (b). The station is the Nam Co Monitoring and Research Station, and it is also the air-sampling site; S01 to S15 represent the 15 sampling sites of surface water around the lake; the red triangle represents the sampling site of seasonal water from May to September.

lake (surface lake water, $0-1 \mathrm{~m}$ depth) were selected to obtain the spatial distribution of OPs in lake water (Fig. 1b), which provides a direct overview of OP contamination over the lake. Second, monthly water samples were collected at a site close to NCMORS (Fig. 1b) from May to September 2014 (water samples were not obtained during winter due to the ice cover). This provided information regarding temporal variations in OP levels, isomer ratios, and the enantiomeric fraction in lake water. Furthermore, coupled with the monthly average air concentrations of individual OPs obtained, this allowed us to investigate the air-water gas exchange of OPs (direction, flux, and monthly variations).

Water samples $(200 \mathrm{~L})$ were filtered with GFFs $(0.7 \mu \mathrm{m}$, Whatman) to obtain the total suspended particulate matter (SPM), then pumped through an XAD-2 resin column to collect the dissolved-phase compounds. For each sampling month, triplicate samples were collected. In total, 15 samples for the spatial study and 15 samples for the temporal study were collected. XAD columns were kept at $4{ }^{\circ} \mathrm{C}$ until extraction. The lake water properties (temperature, $\mathrm{pH}$, and salinity) are provided in Table S2.

\subsection{Sample extraction and analysis}

The chemical extraction and clean-up methods are detailed in Text S1 for each sample type [air (PUF plug), TSP, water (XAD column), and SPM]. OPs were analysed on a gas chromatograph with an ion-trap mass spectrometer (GC-MS, Finnigan Trace GC/PolarisQ) operating under MS-MS mode. More information on the chromatographic conditions is given in Text S2. The target compounds are as follows: $\mathrm{HCHs}$ (including $\alpha-\mathrm{HCH}, \beta-\mathrm{HCH}$, and $\gamma-\mathrm{HCH}), \mathrm{HCB}, \mathrm{DDTs}\left(o, p^{\prime}\right.$-DDE, $p, p^{\prime}$-DDE, $o, p^{\prime}-$ DDT, and $p, p^{\prime}$-DDT), PCBs (PCB 28, PCB 52, PCB 101, PCB 138, PCB 153, and PCB 180), and 15 priority PAHs listed by the United States Environment Protection Agency (USEPA, without naphthalene), including ace- naphthylene (Acel), acenaphthene (Ace), fluorene (Flu), phenanthrene (Phe), anthracene (Ant), fluoranthene (Fla), pyrene (Pyr), benz[a]anthracene (BaA), chrysene ( $\mathrm{Chr}$ ), benzo[b]fluoranthene (Bbf), benzo[k]fluoranthene (Bkf), benzo[a]pyrene (BaP), dibenz[a, h]anthracene (DahA), benzo[g, h, i]perylene (BghiP), and indeno[1,2,3-cd]pyrene (IcdP). Enantiomers of $\alpha-\mathrm{HCH}$ were determined with a BGB-172 chiral column (see Text S2 for details). The chiral signature of $\alpha-\mathrm{HCH}$ is expressed using the enantiomeric fraction (EF), which is equal to the ratio of peak areas of the $(+) /[(+)+(-)]$ (Harner et al., 2000).

\subsection{Quality assurance/quality control (QA/QC)}

All analytical procedures were monitored using strict QA/QC measures. Prior to sampling, PUF and XAD resin were precleaned using dichloromethane (DCM) for $16 \mathrm{~h}$ and GFFs were baked at $450^{\circ} \mathrm{C}$ for $4 \mathrm{~h}$. Six PUF field blanks, three XAD field blanks, and six procedural blanks were prepared; HCB, Phe, Ant, Fla, and Pyr were detected in the field blanks (Table S3). The definitions of the method detection limits (MDLs) are described in Text S3, and the derived MDLs are given in Table S4. The breakthrough of PUF plugs was checked in 11 split PUFs, and the results show that the individual OPs in the second half varied from 8 to $23 \%$ (Table S5), indicating good retention capacity. Certified surrogate standards (from Dr. Ehrenstorfer GmbH, Germany) were added to each sample before extraction and analysis. The recoveries ranged from 71 to $94 \%$ for PCB 30, 79 to $105 \%$ for Mirex, and 65 to $92 \%$ for perylene-D12. The reported concentrations were subtracted by mean blanks but not corrected for recoveries. To check the reproducibility of the chiral analysis, the racemic standard of $\alpha-\mathrm{HCH}$ was injected repeatedly and its average EF value was $0.499 \pm 0.001$ $(n=5)$. 


\subsection{Calculations of air-water gas exchange}

Concurrent air and water samples were used to assess the status of air-water gas exchange in Nam Co lake. The gas exchange direction can be determined by the ratio of fugacity in water $\left(f_{\mathrm{w}}\right)$ and air $\left(f_{\mathrm{a}}\right)$, giving the fugacity ratio $\left(f_{\mathrm{w}} / f_{\mathrm{a}}\right)$ (Jantunen et al., 2015):

$f_{\mathrm{a}}=C_{\mathrm{G}} R T_{\mathrm{a}}$

$f_{\mathrm{w}}=C_{\mathrm{w}} H$

where $C_{\mathrm{G}}$ and $C_{\mathrm{w}}$ are the gaseous and dissolved concentrations of target compounds in the air and water $\left(\mathrm{mol} \mathrm{m}^{-3}\right), R$ is the gas constant $\left(8.314 \mathrm{~Pa} \mathrm{~m}^{3} \mathrm{~mol}^{-1} \mathrm{~K}^{-1}\right), T_{\mathrm{a}}(\mathrm{K})$ is the air temperature, and $H\left(\mathrm{~Pa} \mathrm{~m}^{3} \mathrm{~mol}^{-1}\right)$ is the Henry's law constant. Due to the possible sorption by dissolved organic carbon (DOC), OPs retained by XAD were DOC corrected to derive the truly freely dissolved concentrations in water (Text S4) (Gonzalez-Gaya et al., 2016). $H$ values were adjusted for the real water temperature and salinity of Nam Co by the procedure described in Text S5 (Cetin et al., 2006; Ma et al., 2010). The uncertainty involved in $f_{\mathrm{w}} / f_{\mathrm{a}}$ was estimated by propagating the errors in $C_{\mathrm{a}}(30 \%), C_{\mathrm{w}}(35 \%)$, and $H(20 \%)$, which was $50 \%$. Accordingly, ratios of $f_{\mathrm{w}} / f_{\mathrm{a}}$ between 0.5 and 1.5 are assumed to be at air-water equilibrium, while $f_{\mathrm{w}} / f_{\mathrm{a}}>1.5$ and $<0.5$ indicate net volatilization and deposition.

Net fluxes of air-water gas exchange $\left(F_{\mathrm{AW}}, \mathrm{ng} \mathrm{m}^{-2} \mathrm{~d}^{-1}\right)$ were quantified using the Whitman two-film model, which has been used in many previous studies (Iwata et al., 1993; Khairy et al., 2014):

$F_{\mathrm{AW}}=K_{\mathrm{ol}}\left(C_{\mathrm{w}}-C_{\mathrm{G}} R T_{\mathrm{a}} / H\right)$,

where $K_{\mathrm{ol}}\left(\mathrm{m} \mathrm{s}^{-1}\right)$ is the overall mass transfer coefficient, which contains contributions from the mass transfer coefficients of the water and air layers, $K_{\mathrm{w}}$ and $K_{\mathrm{a}}$. They are related to the wind speed and compound-specific molecular diffusivity; a detailed calculation is presented in Text S6. Positive flux values indicate net volatilization, and negative values indicate net deposition.

\subsection{Estimation of dry and wet deposition fluxes}

In addition to the gas exchange, dry and wet deposition are also important processes that control the input of OPs from the air to the lake. Dry deposition fluxes $\left(F_{\mathrm{DD}}, \mathrm{ng} \mathrm{m}^{-2} \mathrm{~d}^{-1}\right)$ of atmospheric particulate-phase OPs can be calculated using (Gonzalez-Gaya et al., 2016) the following equation:

$F_{\mathrm{DD}}=0.864 V_{\mathrm{D}} C_{\mathrm{P}}$

where $V_{\mathrm{D}}\left(\mathrm{cm} \mathrm{s}^{-1}\right)$ is the compound-specific deposition velocity, $C_{\mathrm{P}}$ is the measured OP concentrations in TSP $\left(\mathrm{pg} \mathrm{m}^{-3}\right)$, and 0.864 is a unit conversion factor. $V_{\mathrm{D}}$ for each sampling period and compound was estimated using an empirical equation derived by Gonzalez-Gaya et al. (2014):

$\log \left(V_{\mathrm{D}}\right)=-0.261 \log \left(P_{\mathrm{L}}\right)+0.387 U_{10} \mathrm{Chl}_{\mathrm{s}}-3.082$, where $P_{\mathrm{L}}(\mathrm{Pa})$ is the subcooled liquid vapour pressure of the chemicals that was corrected to the local temperature using the equations given in Table $\mathrm{S} 6, U_{10}\left(\mathrm{~m} \mathrm{~s}^{-1}\right)$ is wind speed at $10 \mathrm{~m}$ height converted from the field-measured wind speed at $1.5 \mathrm{~m}$ (Table S1), and Chls is the surface chlorophyll concentration ( $\mathrm{mg} \mathrm{m}^{-3}$, Liu et al., 2010).

Wet deposition fluxes by rain $\left(F_{\mathrm{WD}}, \mathrm{ng} \mathrm{m}^{-2} \mathrm{~d}^{-1}\right)$ were estimated using the method established by Jurado et al. (2005):

$F_{\mathrm{WD}}=P\left(W_{\mathrm{G}} C_{\mathrm{G}}+W_{\mathrm{P}} C_{\mathrm{P}}\right)$,

where $P$ is precipitation depth per day $\left(\mathrm{m} \mathrm{d}^{-1}\right)$ derived from the data recorded in the NCMORS, and $W_{\mathrm{G}}$ and $W_{\mathrm{P}}$ are the gas and particle washout ratios. Assuming that equilibrium is attained between the gas phase and the dissolved phase in a raindrop, $W_{\mathrm{G}}$ was estimated by (Wania et al., 1998a)

$W_{\mathrm{G}}=R T_{\mathrm{a}} / H$.

The recommended value of $W_{\mathrm{P}}$ in Jurado et al. (2005) was used to consider particle scavenging by rain.

For snow deposition, the fluxes were calculated by adopting the washout ratios reported in Franz and Eisenreich (1998) (Table S7).

\section{Results and discussion}

We determined the OP concentrations in the air, TSP, water, and SPM separately; the full data sets are listed in Tables S8-S11. OCPs and PCBs were rarely detected in TSP (Table S9), and were therefore not considered in further discussions. Comparisons between the data from this study and previously published values for the TP and other remote regions are presented in Tables S12-S15.

\subsection{Levels of OPs in air and water at Nam Co}

The concentrations of OPs in the atmosphere and TSP in Nam Co are summarized in Fig. 2 using box-and-whisker plots. Among the OCPs, HCB was the dominant chemical with an average concentration of $20 \mathrm{pg} \mathrm{m}^{-3}$ (Fig. 2a), which was two times higher than that reported for southeastern TP (Sheng et al., 2013) and Mt Everest (Li et al., 2006) (Table S12), but lower than the values in the Rocky Mountains (42 $\mathrm{pg} \mathrm{m}^{-3}$, Wilkinson et al., 2005) and the Arctic (64 $\mathrm{pg} \mathrm{m}^{-3}$, Su et al., 2006). The $\alpha-\mathrm{HCH}$ (average $\left.4.0 \mathrm{pg} \mathrm{m}^{-3}\right)$ and $\gamma-\mathrm{HCH}\left(2.1 \mathrm{pg} \mathrm{m}^{-3}\right)$ values in this study were much lower than those measured using a flow-through sampler (FTS) from 2006 to 2008 (48.7 and $7.9 \mathrm{pg} \mathrm{m}^{-3}$ respectively) (Xiao et al., 2010). The DDT concentrations in the current study $\left(0.8-46.4 \mathrm{pg} \mathrm{m}^{-3}\right)$ were lower than those observed for Lulang in south-eastern TP (Table S12) (Sheng et al., 2013), which is the entrance of the Indian monsoon. In spite of this, the levels of DDTs were still 1 order of magnitude higher than those for the Arctic (Table S12) (Su et al., 


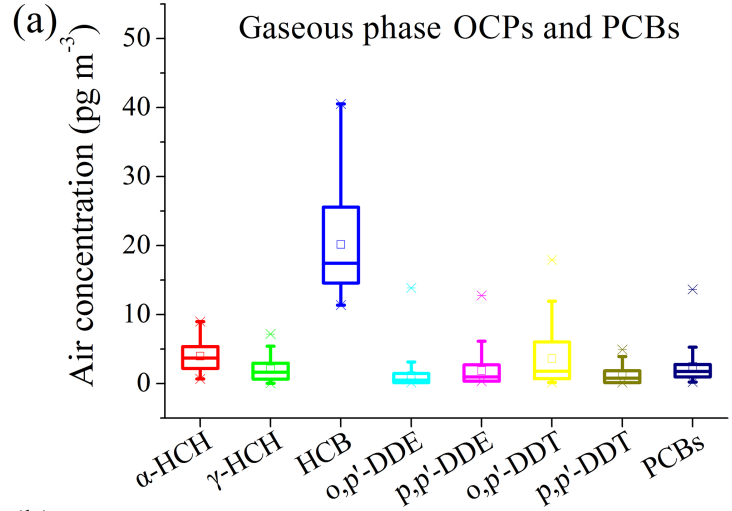

(b)

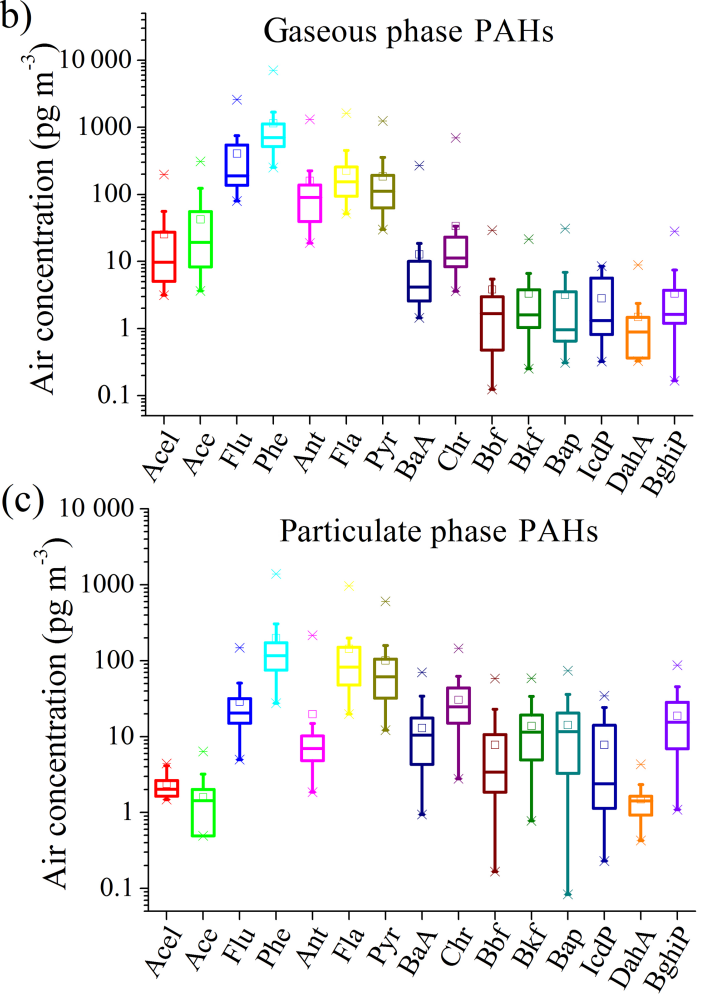

Figure 2. Air concentrations of gaseous OCPs and PCBs (a), gaseous PAHs (b), and particulate-phase PAHs (c) in Nam Co. The boxes are defined by the 25 th and 75 th percentiles, whiskers mark the 10th and 90th percentiles, the median is represented by a horizontal line, the mean by a square, and outliers with an asterisk.

2008). Lower concentrations of $\sum_{6} \mathrm{PCBs}$ were also detected in the air with an average value of $2.5 \mathrm{pg} \mathrm{m}^{-3}$.

The sum concentrations of $\sum_{15}$ PAHs in the atmosphere ranged from $0.5-13$ and $0.1-3.4 \mathrm{ng} \mathrm{m}^{-3}$ in the gaseous and particulate phases, with averages of 2.2 and $0.6 \mathrm{ng} \mathrm{m}^{-3}$ respectively. The 3- and 4-ring PAHs were predominant in both phases, including Phe, Flu, Fla, and Pyr (Fig. 2b and c). The PAH levels in Nam Co were 1 order of magnitude lower than those reported for Lhasa (35.7 $\mathrm{ng} \mathrm{m}^{-3}$, Table S13), which is the capital city of Tibet and has a large population, extensive tourism, and abundant religious activities (Gong et al.,
2011). Compared with background levels in other regions of the world (Table S13), the PAHs in this study were comparable to the levels in Arctic air (Ding et al., 2007), but were significantly higher than those from European mountainous regions (Fernandez et al., 2002).

In the lake water, the average dissolved concentrations of $\alpha-\mathrm{HCH}, \beta-\mathrm{HCH}, \gamma-\mathrm{HCH}, \mathrm{HCB}$, and PCB 28 were 9.9, 85.2, 7.0, 7.6, and $1.9 \mathrm{pg} \mathrm{L}^{-1}$, while DDT-related compounds were below MDLs in most cases for both dissolved and SPM phases (Tables S10 and S11). The current measured $\mathrm{HCH}$ concentrations were approximately 2 orders of magnitude lower than values reported for the Yamdrok and Co Ngoin Lake in 2002 (Table S14) (Zhang et al., 2003). Two possible reasons for this discrepancy are (i) the interannual variation of chemicals; i.e. the concentrations declined rapidly since 2002; and (ii) the uncertainties caused by analytical and instrumental method (electron capture detector in Zhang et al. (2003) study and the MS detector in the current study). From a global perspective, the $\mathrm{HCH}$ concentrations obtained by this study were overall lower than those in European mountain lakes (Table S14). DDT class chemicals were rarely detected and only PCB 28 could be quantified in the Nam Co lake water. These features combined with the low levels of HCHs suggest that the OP levels in Nam Co lake water were close to the values reported for ocean waters, such as the North Atlantic and Arctic oceans (with DDTs and PCBs mostly below the detection level, or $<1 \mathrm{pg} \mathrm{L}^{-1}$ ) (Gioia et al., 2008; Lohmann et al., 2009). By contrast, high levels of PAHs were found in the Nam Co lake water, ranging from 6.9 to 83.6 and 1.7 to $28 \mathrm{ng} \mathrm{L}^{-1}$ for the dissolved and SPM phases. The dissolved $\sum_{15} \mathrm{PAH}$ levels were 1 order of magnitude higher than those reported for Himalayan highaltitude lakes in Nepal (Table S15) (Guzzella et al., 2011) and the Great Lakes (Table S15) (Venier et al., 2014), and 2 orders of magnitude greater than values for open oceans (Table S15) (Ma et al., 2013) and European mountain lakes (Table S15) (Vilanova et al., 2001).

\subsection{Possible sources}

Long-range atmospheric transport (LRAT) is considered an important source for the occurrence of OPs in remote environments (Dalla Valle et al., 2005). Considering that the prevailing climate system operating over Nam Co in summer is the Indian monsoon, if the seasonal pattern of a chemical is similar to that of the monsoon, monsoon transport may therefore be the source of OPs in Nam Co air. Thus, the interrelationship between monsoon intensity (Indian monsoon index, IMI, $\mathrm{W} \mathrm{m}^{-2}$ ) and OP concentrations was investigated (Fig. 3). Figure 3 shows that $\alpha-\mathrm{HCH}$ and $o, p^{\prime}$-DDT displayed synchronous seasonal variation with the IMI. This suggests that monsoon transport was the principal reason for the occurrence of OCPs in the Nam Co atmosphere. In addition, isomer ratios can provide insight into the source and fate of the OPs. In this study, we found that the isomer ratios 


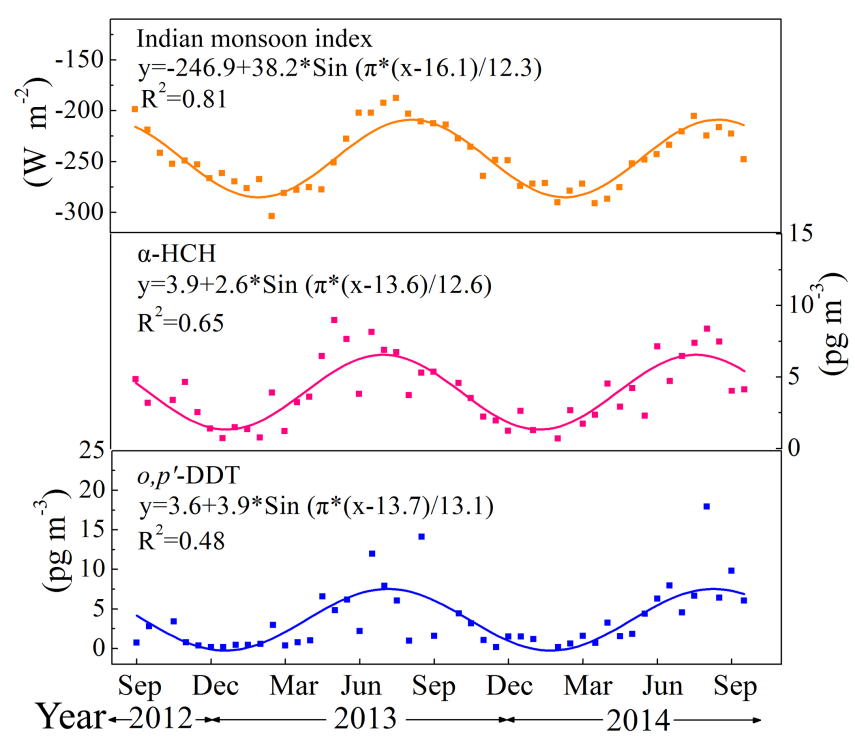

Figure 3. Seasonal patterns of the Indian monsoon index, the atmospheric concentrations of $\alpha-\mathrm{HCH}$ and $o, p^{\prime}$-DDT.

of $p, p^{\prime}$-DDT to $p, p^{\prime}$-DDE were broadly in agreement with those found for the source regions of India and the Bay of Bengal (Table S16) (Gioia et al., 2012; Zhang et al., 2008). Similar to other remote regions, such as the Arctic (Hung et al., 2010), Antarctic (Baek et al., 2011), Rocky Mountains (Daly et al., 2007), and south-eastern TP (Sheng et al., 2013), in which LRAT is the primary transport mode of OPs, the dominance of $\alpha$ - to $\gamma$-HCH was observed in the Nam Co atmosphere (Table S16). Results of isomer ratios associated with the seasonal variations supported the interpretation that OCPs in the Nam Co atmosphere had undergone LRAT. In contrast to OCPs, neither the gaseous nor the particulate phases of PAHs showed a clear and consistent seasonal variation during the 2 years of air monitoring (Fig. S3), which is likely because there were primary emissions of PAHs surrounding the Nam Co region.

Apart from the seasonal trends, spatial distribution patterns can also provide valuable information on OP sources. The spatial distributions of OPs in the surface water across the Nam Co lake are presented in Fig. 4. First, HCHs showed a uniform distribution (Fig. 4a) without significant differences among the different regions of the lake (Table S17). The even distribution of $\mathrm{HCHs}$ in the water was most likely caused by the LRAT origins and relatively higher water solubility. Second, relatively high levels of HCB and PAHs occurred in water from the north-western and eastern parts of the lake (Table S17, Fig. 4b and c). The elevated HCB and PAHs in these regions were likely related to anthropogenic activity in the vicinity. As shown in Fig. 1b, two townships (Baoji and Namco), which have the highest populations around Nam Co lake, are located at the north-western and eastern corners of the lake. Following a traditional lifestyle, (a)

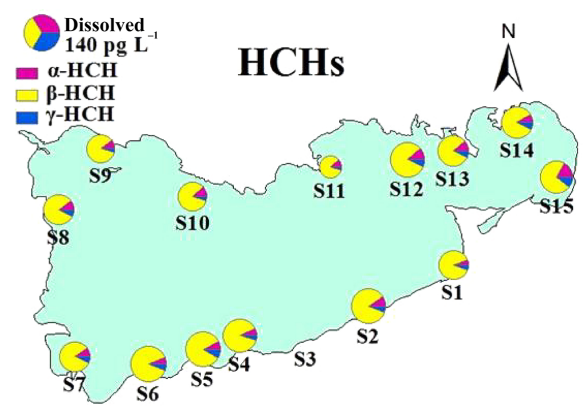

(b)

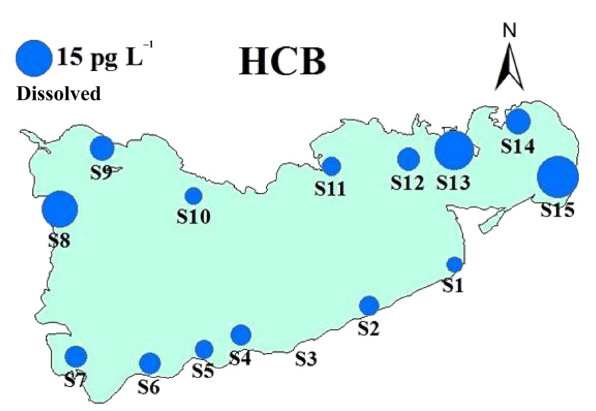

(c)

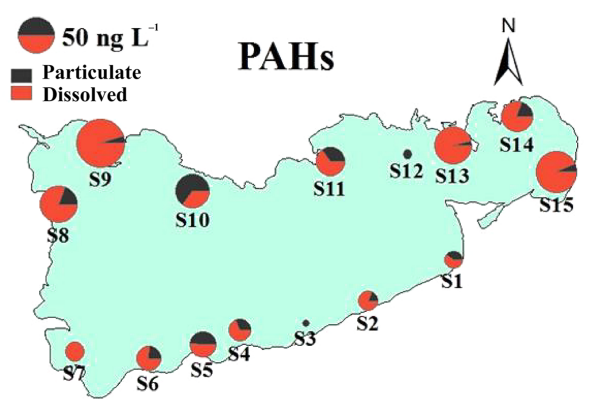

Figure 4. Spatial distribution pattern of $\mathrm{HCHs}(\mathbf{a}), \mathrm{HCB}$ (b), and PAHs (c) in the surface water of Nam Co lake.

the residents use large amounts of local biomass (mostly yak dung) for cooking and heating (Xiao et al., 2015). High PAH concentrations have been reported in local Tibetan tents which were emitted mainly from burning yak dung ( $\mathrm{Li}$ et al., 2012). A ratio of $\mathrm{BaA} /(\mathrm{BaA}+\mathrm{Chr})=0.33$ was recommended as a specific diagnostic fingerprint for yak dung combustion ( $\mathrm{Li}$ et al., 2012). The $\mathrm{BaA} /(\mathrm{BaA}+\mathrm{Chr})$ ratios observed in our study $(0.27 \pm 0.08$ for air and $0.24 \pm 0.10$ for water) were in good agreement with this diagnostic ratio. This suggests that local combustion emissions are likely to be the source of PAHs in Nam Co. With the exception of PAHs, biomass combustion can also produce HCB (Bailey, 2001), which may be the reason for the higher HCB concentrations around the townships. The spatial distribution of OPs in the Nam Co lake water highlights the important contribution of local sources for PAHs and HCB. 


\subsection{LRAT versus revolatilization}

From the above results, we found that LRAT is a key factor that determines the seasonality of the atmospheric $\mathrm{HCHs}$ and DDTs in Nam Co (higher concentrations occurred in summer). However, high temperatures generally occur during summer, which may promote the evaporation of chemicals from local surfaces (e.g. soils and water bodies). To what extent does this re-evaporation contribute to the atmospheric OPs? The Clausius-Clapeyron (C.C.) equation can be used to assess this probability (Wania et al., 1998b). If a strong relationship is found between the partial pressure of atmospheric OCPs and the air temperature, this indicates that volatilization may occur. Otherwise, low temperature dependence will occur in the case of LRAT. In the present study, the results of the C.C. equation are summarized in Table S18. The correlation with temperature ( $p>0.05$, Table S18) for most chemicals was not significant, except for $\alpha-\mathrm{HCH}$, which displayed a relatively lower correlation coefficient $\left(R^{2}=0.29\right.$, $p<0.05$, Table S18). This indicates that weak volatilization of $\alpha-\mathrm{HCH}$ from local surfaces at Nam Co may exist, while the re-evaporation of other chemicals is limited.

Enantiomers of chiral OPs have been used to distinguish the contribution of LRAT and revolatilization of OPs from surfaces (Bidleman et al., 2012). For example, technical $\mathrm{HCH}$ contains the (+)- and $(-)-\alpha-\mathrm{HCH}$ enantiomers in a racemic proportion $(\mathrm{EF}=0.5)$. Abiotic processes (transport, hydrolysis, and photolysis) do not favour either enantiomer, while only biological processes, such as microbial degradation in soils and water, show enantioselectivity and will alter the EFs of $\alpha-\mathrm{HCH}$ (Ridal et al., 1997). Therefore, nearracemic signatures usually indicate input from LRAT, while non-racemic signatures represent the influence of local microbial degradation. In the present study, both the enantiomeric signatures of $\alpha-\mathrm{HCH}$ in the air and water were measured simultaneously from May to September. As shown in Fig. 5a, all the lake water samples showed a selective depletion of $(+) \alpha-\mathrm{HCH}$, with EFs ranging from 0.318 to 0.449 . This has previously been reported for other cold oligotrophic water systems, such as the Arctic lakes (EFs: 0.3590.432) (Law et al., 2001). From Fig. 5a, we found that extensive enantioselective degradation occurred in June and July, which coincided with the bacterial bloom period (Fig. 5b) (Liu et al., 2013). This negative correlation between the EF of $\alpha-\mathrm{HCH}$ in lake water and bacterial abundance is presented in Fig. S4. Law et al. (2001) suggested that under low nutrient conditions, oligotrophic bacteria are able to use xenobiotic carbon sources, such as $\alpha-\mathrm{HCH}$. This implies that the Tibetan lake microbes can also metabolize, or cometabolize, $\alpha-\mathrm{HCH}$.

If high temperatures favour the evaporation of $\alpha-\mathrm{HCH}$ from the lake water, depletion of $(+) \alpha-\mathrm{HCH}$ should be observed for air. However, overall the EFs of the air samples were racemic. This is similar to the racemic composition observed in the atmosphere over Indian regions (Huang et al.,
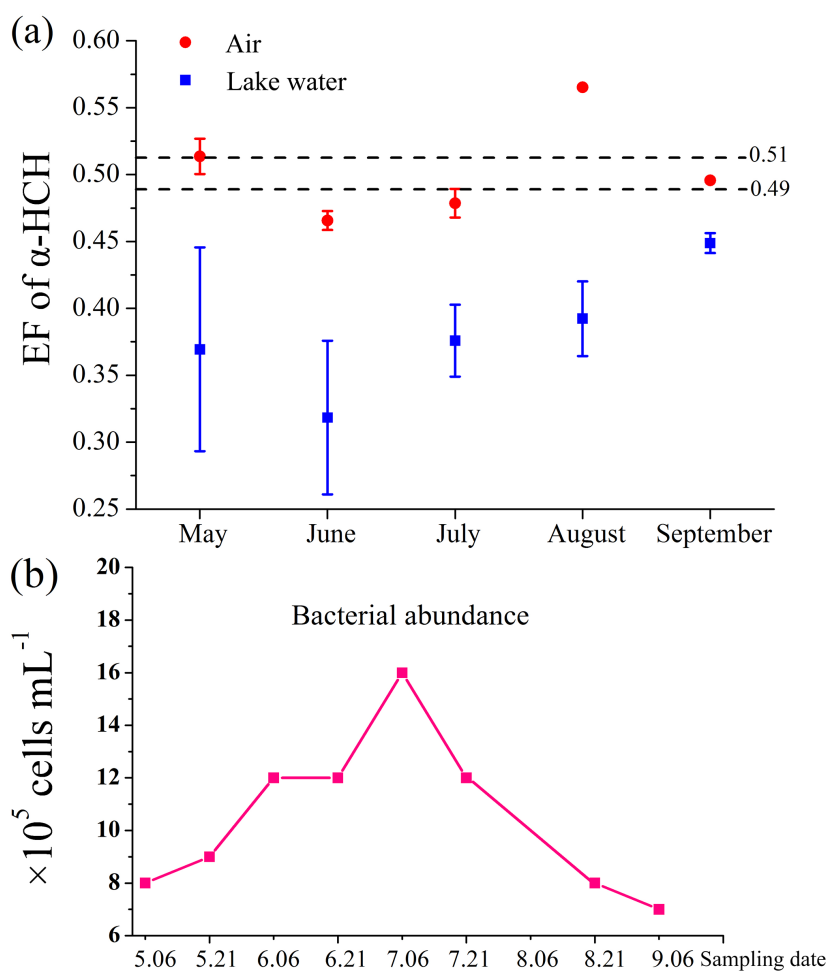

Figure 5. Enantiomer fraction (EF) of $\alpha-\mathrm{HCH}$ in the air and surface water from May to September (a), and the seasonal bacterial abundance in Nam Co lake water (b). The data of bacterial abundance was derived from Liu et al. (2013), which represents the total bacteria in the lake surface water.

2013), which are the potential source regions of HCHs in Nam Co. With respect to the enantiomeric signature in air samples from June and July, only some $(+) \alpha-\mathrm{HCH}$ depletion was observed in the air (Fig. 5a), indicating weak evaporation of $\alpha-\mathrm{HCH}$ from the lake water. Combined with the EF values in air and water, the fraction of the contribution from lake water volatilization $(f)$ can be quantified by (Huang et al., 2013)

$f=\left(\mathrm{EF}_{\mathrm{a}}-\mathrm{EF}_{\mathrm{b}}\right) /\left(\mathrm{EF}_{\mathrm{w}}-\mathrm{EF}_{\mathrm{b}}\right)$,

where $\mathrm{EF}_{\mathrm{a}}$ and $\mathrm{EF}_{\mathrm{w}}$ are the $\mathrm{EF}$ values in air and water, and $\mathrm{EF}_{\mathrm{b}}$ is the background $\mathrm{EF}$ value in air, which was assumed to be the average EF of the standard. The estimated results show that only 19 and $17 \%$ of atmospheric $\alpha-\mathrm{HCH}$ came from water volatilization in June and July, demonstrating that LRAT is indeed the major source (more than $80 \%$ ) of $\alpha$ $\mathrm{HCH}$. This result is in contrast with the conclusion of Xiao et al. (2010), who reported that evaporation from Nam Co lake largely contributes to the atmospheric $\alpha-\mathrm{HCH}$ concentration. In that study, both levels and enantiomeric signatures of $\alpha$ $\mathrm{HCH}$ in Nam Co lake water were absent. 

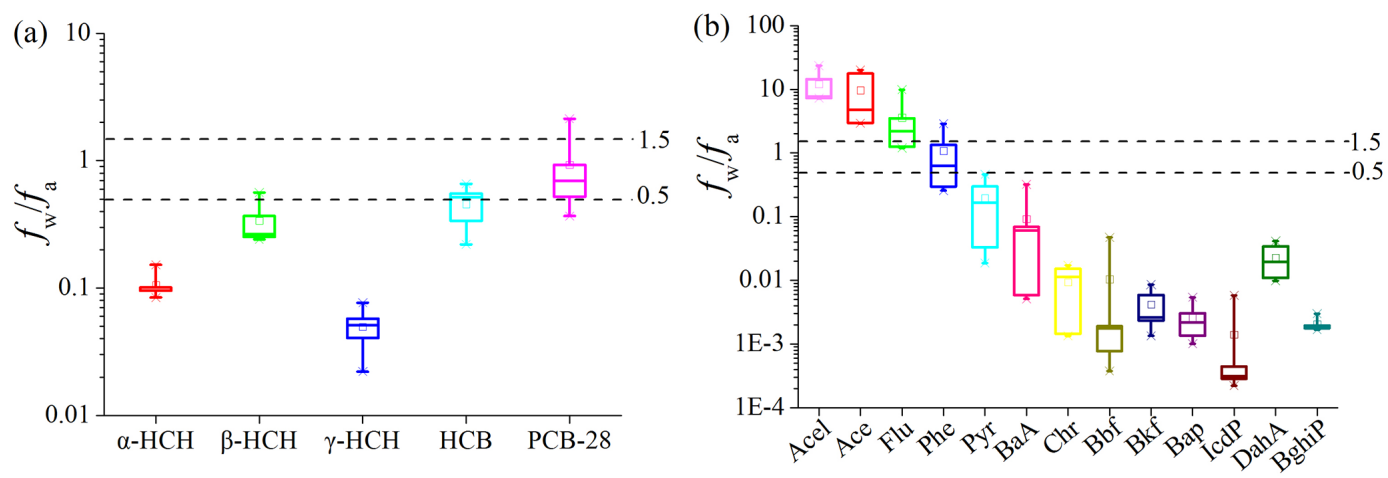

Figure 6. Water/air fugacity ratios $\left(f_{\mathrm{w}} / f_{\mathrm{a}}\right)$ for OCPs and PCB 28 (a), and individual PAHs (b) in Nam Co lake. The horizontal lines represent the uncertainty range, $0.5-1.5$ was considered to be at equilibrium.

\subsection{Atmospheric processes}

\subsubsection{Air-water gas exchange}

Although some $\alpha-\mathrm{HCH}$ evaporation was recorded in June and July, the air-water exchange process during the entire ablation period is of great importance as this is the main season for transferring pollutants between air and water. Fugacity ratios $\left(f_{\mathrm{w}} / f_{\mathrm{a}}\right)$ and net exchange fluxes $\left(F_{\mathrm{AW}}, \mathrm{ng}\right.$ $\mathrm{m}^{-2} \mathrm{~d}^{-1}$ ) were quantified using paired air-water samples collected from May to September in 2014. The average exchange status (average of $f_{\mathrm{w}} / f_{\mathrm{a}}$ ) for HCHs, HCB, PCB 28, and PAHs during the ablation period is illustrated in Fig. 6. Because of DDTs, Ant and Fla were not quantified in the lake water (Table S10) and were therefore excluded from the discussion. $\alpha$ - and $\gamma$-HCH had low $f_{\mathrm{w}} / f_{\mathrm{a}}$ values ranging from 0.08 to 0.15 , and 0.02 to 0.08 (Fig. 6a). The low $f_{\mathrm{w}} / f_{\mathrm{a}}$ ratio suggests that $\alpha$ - and $\gamma-\mathrm{HCH}$ were overall prone to deposition from the air to the water during the ablation period. The deposition fluxes were $-1.6 \pm 0.4 \mathrm{ng} \mathrm{m}^{-2} \mathrm{~d}^{-1}$ for $\alpha-\mathrm{HCH}$ and $-1.0 \pm 0.2 \mathrm{ng} \mathrm{m}^{-2} \mathrm{~d}^{-1}$ for $\gamma-\mathrm{HCH}$, which are within the same order of magnitude as those reported for the Great Lakes (Khairy et al., 2014). Connected to the source of HCHs discussed above, this result implies that the following LRAT-deposition event of HCHs occurred in the ablation period of Nam Co lake. In terms of $\beta-\mathrm{HCH}$, $\mathrm{HCB}$, and PCB 28 , their $f_{\mathrm{w}} / f_{\mathrm{a}}$ ratios were either overlapping with the equilibrium range $(0.5-1.5)$ or on the edge of deposition threshold. Therefore, low deposition fluxes for $\beta$-HCH $\left(-0.2 \mathrm{ng} \mathrm{m}^{-2} \mathrm{~d}^{-1}\right)$ and PCB $28\left(-0.1 \mathrm{ng} \mathrm{m}^{-2} \mathrm{~d}^{-1}\right)$, and large variability for HCB $\left(-1.0 \pm 0.6 \mathrm{ng} \mathrm{m}^{-2} \mathrm{~d}^{-1}\right)$ were observed (Fig. 7a).

The results of the air-water gas exchange for PAHs are presented in Fig. 6b. The fugacity ratios of 13 PAHs varied depending on their molecular weight and volatility (Fig. 6b). Acel, Ace, and Flu showed $f_{\mathrm{w}} / f_{\mathrm{a}}$ values significantly higher than 1.5 (Fig. 6b), indicating that the lake acted as a secondary source for these volatile chemicals. The $f_{\mathrm{w}} / f_{\mathrm{a}}$ values for Phe covered a large range (from 0.3 to 3 ), showing a shift between volatilization and deposition (Fig. 6b). Other high molecular weight (MW > 202) PAHs, including Pyr, BaA, Chr, Bbf, Bkf, Bap, IcdP, DahA, and BghiP, favoured net deposition with $f_{\mathrm{w}} / f_{\mathrm{a}}$ values lower than 0.5 (Fig. 6b). Greater volatilization fluxes were observed for Acel, Ace, and Flu (3-ring), which could reach up to $203 \mathrm{ng} \mathrm{m}^{-2} \mathrm{~d}^{-1}$ (Fig. 7b). Whereas, the gaseous deposition fluxes for high molecular weight PAHs were 2 orders of magnitudes lower and only varied from -1.0 to $-4.6 \mathrm{ng} \mathrm{m}^{-2} \mathrm{~d}^{-1}$ (Fig. 7c). Although average deposition fluxes of $339 \mathrm{ng} \mathrm{m}^{-2} \mathrm{~d}^{-1}$ were calculated for Phe, the deposition fluxes showed large variability ( $\left.\pm 604 \mathrm{ng} \mathrm{m}^{-2} \mathrm{~d}^{-1}\right)$. This result is broadly consistent with the exchange direction revealed by the $f_{\mathrm{w}} / f_{\mathrm{a}}$ values, implying that the exchange of Phe between air and water may be reversed during the entire ablation period.

\subsubsection{Reversal of the air-water exchange of Phe}

In Sect. 3.4.1, we observed that both the air-water exchange direction and the flux of Phe showed a large range of values and uncertainties. This raises the question of what drives this variation. The monthly calculated $f_{\mathrm{w}} / f_{\mathrm{a}}$ and $F_{\mathrm{AW}}$ of Phe during the ablation period showed that the volatilization of Phe occurred during May and June, but deposition begun in July, which represents a reversal (Fig. 8). Given that lake ice begins melting during May, the melted ice may discharge large amounts of accumulated PAHs into the lake, causing the relative enrichment (high fugacity) of Phe in the water, and triggering the secondary emission of Phe from the water to the atmosphere. This was confirmed by the increased water concentration of Phe found during May and June (Table S10). This is also why a large uncertainty of $F_{\mathrm{AW}}$ was observed for Phe during the ablation period. Linked to the source of PAHs discussed above, the final exchange status of PAHs is the combined effects of the depositional input caused by biomass burning, the properties of the chemical, and the melting of lake ice.

Seasonal ice cover is an important feature of water bodies in cold regions. In the Arctic region, Jantunen et al. (2008) 

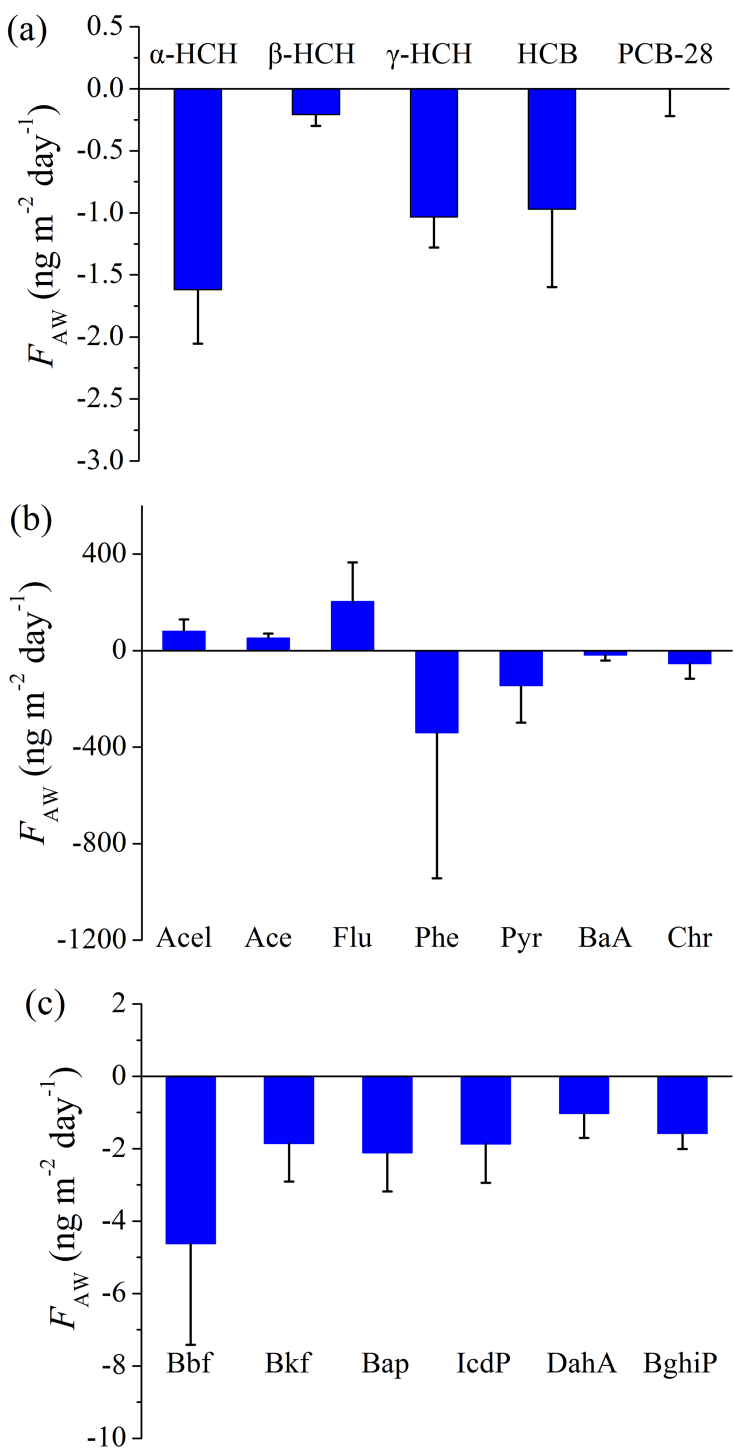

Figure 7. Average air-water gas exchange fluxes $\left(F_{\mathrm{AW}}\right)$ for individual OCPs, PCB 28 (a), and PAHs (b, c) in Nam Co lake. Positive values indicate net volatilization, and negative values indicate net deposition.

and Wong et al. (2011) both observed the occurrence of volatilization of OCPs from seawater coincident with the break-up of ice cover in the summer. The Nam Co lake also undergoes long periods of ice cover (Liu et al., 2013). During the winter, the lake surface is covered by ice, and gas exchange is restricted; meanwhile dry and wet deposition exert a significant influence on the input inventory of PAHs to the lake. Both of these deposition processes are one-way (no volatilization), which keeps the contaminants being accumulated. As summer arrives, the lake ice begins to thaw and air-water gas exchange begins to dominate. On one hand, after the higher accumulation of deposition, supersaturation of PAHs in the lake may occur. On the other hand, the fu-

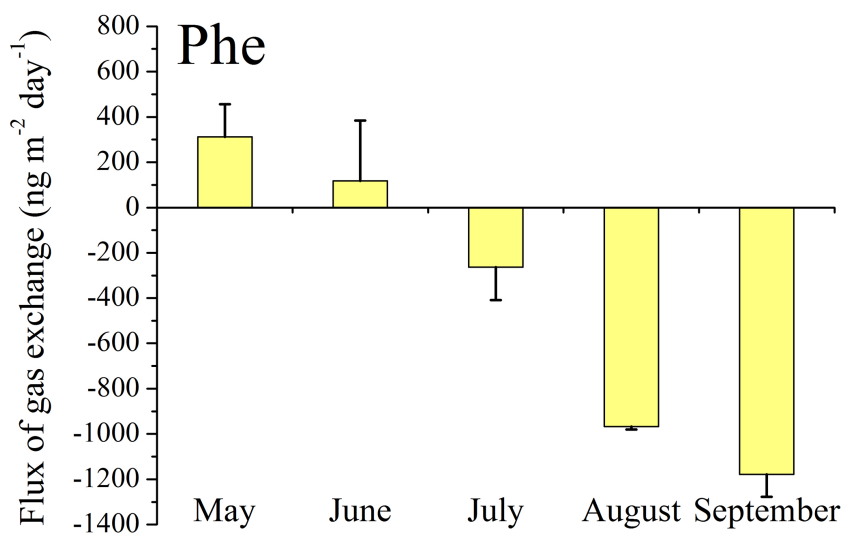

Figure 8. Reversal of the air-water gas exchange for Phe from May to September.

gacity capacity of ice is much higher than that of water, and therefore the decrease of the fugacity capacity during melting will increase the fugacity of the PAHs (Wania et al., 1998c), which also promotes their re-emission from the water. Although the seasonal ice cover did not show any obvious influence on the fate of OCPs and other PAHs, it played an important role in the fate of Phe, which was a dominant compound in the Nam Co atmosphere. The lake therefore acted as a secondary source of Phe in May and June, and shifted to a net sink during other months, which is likely driven by the seasonal freeze-thaw cycle of lake ice (Fig. 8).

\subsubsection{Atmospheric degradation}

Reactions with the hydroxyl radical $(\mathrm{OH})$ are an important removal process of gaseous OPs from the atmosphere. The resulting degradation fluxes $\left(F_{\mathrm{deg}}, \mathrm{ng} \mathrm{m}^{-2} \mathrm{~d}^{-1}\right)$ are dependent on the concentration of $\mathrm{OH}$ radicals in the air (Spivakovsky et al., 2000) and the compound-specific degradation rate constant $\left(K_{\mathrm{OH}}, \mathrm{cm}^{3} \mathrm{~mol}^{-1} \mathrm{~d}^{-1}\right)$. The $K_{\mathrm{OH}}$ values of gaseous OCPs and PAHs are from Brubaker and Hites (1998) and Keyte et al. (2013) respectively. Due to the lack of information on $K_{\mathrm{OH}}$ for $\beta$-HCH and BaA, their degradation fluxes $\left(F_{\text {deg }}\right)$ were not considered in this study. The calculated $F_{\text {deg }}$ values were averaged for individual OPs and are presented in Fig. S5. The degradation fluxes for $\alpha-, \gamma-\mathrm{HCH}, \mathrm{HCB}$, and PCB 28 ranged between 0.3 and $0.9 \mathrm{pg} \mathrm{m}^{-2} \mathrm{~d}^{-1}$ (Fig. S5), 3 orders of magnitude lower than their $F_{\mathrm{AW}}$. This indicates that the contribution of atmospheric degradation to their total inventory in the environment is negligible.

In contrast to the OCPs, the PAHs are more susceptible to photodegradation (Lohmann et al., 2009). In our study, lower molecular weight PAHs showed higher degradation fluxes, such as $4-184 \mathrm{ng} \mathrm{m}^{-2} \mathrm{~d}^{-1}$ for Phe, and $1-160 \mathrm{ng} \mathrm{m}^{-2} \mathrm{~d}^{-1}$ for Ant (Fig. S5). These values are similar to those reported for $F_{\mathrm{deg}}$ in the remote atmosphere of the Atlantic Ocean (i.e. $7-120$ and $9-50 \mathrm{ng} \mathrm{m}^{-2} \mathrm{~d}^{-1}$ for Phe and Ant respectively) (Nizzetto et al., 2008). We observed relatively low 
$F_{\text {deg }}$ values for 5- and 6-ring PAHs, ranging from 0.01 to $0.18 \mathrm{ng} \mathrm{m}^{-2} \mathrm{~d}^{-1}$ (Fig. S5). Generally, the $F_{\text {deg }}$ of all PAH compounds was 1 order of magnitude lower than their $F_{\mathrm{AW}}$. $\mathrm{OH}$ depletion is the primary process that removes atmospheric PAHs, presumably causing the continuous volatilization of low molecular weight PAHs from the water. This raised questions about other processes that may have supplied PAHs to the lake water. On the other hand, $\mathrm{OH}$ degradation also decreases the input of high molecular weight PAHs into the water and it is unclear to what extent this degradation counteracts other deposition processes.

\subsubsection{Atmospheric deposition}

In addition to the gas exchange, dry and wet deposition are also important processes that influence the input of OPs from the air to the lake. Dry $\left(F_{\mathrm{DD}}\right)$ and wet $\left(F_{\mathrm{WD}}\right)$ deposition fluxes were estimated using the method described above (Sect. 2.6). With respect to $\mathrm{HCHs}, \mathrm{HCB}$, and PCB 28, their dry deposition fluxes $\left(F_{\mathrm{DD}}\right)$ were negligible due to their low detection frequency in the particulate phase (Table S9). However, the average $F_{\mathrm{WD}}$ for $\alpha-\mathrm{HCH}, \beta-\mathrm{HCH}$, and $\gamma-\mathrm{HCH}$ were $-0.3,-0.9$, and $-0.4 \mathrm{ng} \mathrm{m}^{-2} \mathrm{~d}^{-1}$, which is comparable to their $F_{\mathrm{AW}}$ levels. $F_{\mathrm{WD}}$ for HCB $\left(-0.02 \mathrm{ng} \mathrm{m}^{-2} \mathrm{~d}^{-1}\right)$ and PCB $28\left(-0.002 \mathrm{ng} \mathrm{m}^{-2} \mathrm{~d}^{-1}\right)$ was 2 orders of magnitude lower than their $F_{\mathrm{AW}}$. In general, precipitation scavenging is most efficient in $\mathrm{HCHs}$ compared with the other chemicals (Carrera et al., 2002). Greater wet deposition fluxes of HCHs occurred in August (Fig. S6), coinciding with the highest amount of precipitation in Nam Co. Combining the $F_{\mathrm{AW}}$ and $F_{\mathrm{WD}}$ of $\mathrm{HCHs}$, the estimated annual input of HCHs from the air into the whole lake $\left(2015 \mathrm{~km}^{2}\right)$ was $1.9 \mathrm{~kg} \mathrm{yr}^{-1}$. This result highlights the input of HCHs by the LRAT-deposition process during the ablation period (open water season). Snow scavenging of $\mathrm{HCHs}$ has been reported as an important clearing process in mountain regions (Kang et al., 2009). However, the transport of $\mathrm{HCHs}$ in winter is very limited due to the unfavourable air circulation patterns (westerly wind), ruling out the significant contribution of $\mathrm{HCHs}$ by snow scavenging.

Compared with OCPs, the close association between PAHs and the particulate phase accounted for their relatively higher deposition fluxes. The estimated dry and wet deposition fluxes for individual PAHs during the ablation and frozen periods respectively are provided in Table 1 . We found that the $F_{\mathrm{DD}}$ values of PAHs for the ablation period are, in general, lower than those for the frozen period. For example, the $F_{\mathrm{DD}}$ of total $\sum_{15}$ PAHs increased by 1 order of magnitude from the ablation period $\left(4.5 \mathrm{ng} \mathrm{m}^{-2} \mathrm{~d}^{-1}\right)$ to the frozen period (38 $\mathrm{ng} \mathrm{m}^{-2} \mathrm{~d}^{-1}$; Table 1). Two factors may lead to an increase of $F_{\mathrm{DD}}$ in winter: the increased wind speed during the winter season and the growing particulate-PAH concentrations due to the enhanced combustion activities in winter. Compared with other studies, the estimated $F_{\mathrm{DD}}$ for the total $\sum_{15}$ PAHs (4.5-38 $\mathrm{ng} \mathrm{m}^{-2} \mathrm{~d}^{-1}$, this study) is broadly within the range reported for global oceans (8.3-52.4 $\mathrm{ng} \mathrm{m}^{-2} \mathrm{~d}^{-1}$ ) (Gonzalez-Gaya et al., 2014).

Wet deposition was found to be the dominant deposition process for the input of PAHs into Nam Co (Table 1). This was expected because precipitation scavenging of organic chemicals underlies the accumulation of pollutants in mountain regions (Tremolada et al., 2008). In addition, there was an obvious difference between the values of $F_{\mathrm{WD}}$ during the ablation and frozen periods. For the total 15 PAHs, the $F_{\mathrm{WD}}$ in the frozen period $\left(702 \mathrm{ng} \mathrm{m}^{-2} \mathrm{~d}^{-1}\right)$ was approximately five times higher than that for the ablation period $\left(161 \mathrm{ng} \mathrm{m}^{-2} \mathrm{~d}^{-1}\right.$ ), which may be due to the different precipitation types between these two periods (snow vs. rain). Snow has been suggested to be more efficient than rain for scavenging particulate PAHs, which had a high concentration during winter in Nam Co (Table S9). Thus, although the precipitation of Nam Co in winter is low (less than $30 \mathrm{~mm}$, Fig. S2), the strong scavenging ratio of snow to PAHs combined with the relatively high particulate-PAH concentration in winter caused enhanced PAH deposition in winter. The frozen season coincided with the period of high emission and high deposition of PAHs, implying a significant contribution in this season of PAHs into the lake.

To calculate the comprehensive contribution of all abovementioned processes, three groups of PAHs were classified in Table 1 based on their fate during the air-water exchange processes. PAHs (Acel, Ace, and Flu) showing volatilization behaviour were placed into one group, PAHs with large $F_{\mathrm{AW}}$ variability between the status of volatilization and deposition were in the second group, and the remaining PAHs displaying deposition behaviour were placed into the third group (Table 1). In this classification, although the air-water exchange direction and fluxes of Ant and Fla cannot be estimated, we still placed them into the second group because of their similarity to Phe in their physicochemical properties. For the volatilization group, the total outgassing from the lake was estimated to be approximately $126 \mathrm{~kg}$ per year, which cannot alone be supplied by their total deposition flux (sum of $F_{\mathrm{WD}}$ and $F_{\mathrm{DD}}$ ). This suggests that there may be additional natural sources of PAHs in the lake, such as degradation of pigments carrying aromatic structure and turnover of organic matter (Nizzetto et al., 2008). Regarding the deposition group (Pyr, BaA, Chr, Bbf, Bkf, Bap, IcdP, DahA, and BghiP), their total deposition flux $\left(F_{\mathrm{AW}}+F_{\mathrm{DD}}+F_{\mathrm{WD}}\right)$ will roughly cause an annual input of $208 \mathrm{~kg}$ high molecular weight PAHs into the lake. Although the $F_{\mathrm{AW}}$ of Phe was reversed and the total volatilization of Phe was estimated at around $26 \mathrm{~kg} \mathrm{yr}^{-1}$, this loss will be complemented by the continuous deposition of Phe $\left(\sim 373 \mathrm{~kg} \mathrm{yr}^{-1}\right)$ from July to April. This indicates that the annual net input of Phe will be above $340 \mathrm{~kg}$, which suggests that Phe is the most dominant contributor to the total PAH deposition. In addition to the 15 PAHs considered here, there are other PAHs with high abundances, for example alkylated phenanthrenes, 
Table 1. Estimated fluxes $\left(\mathrm{ng} \mathrm{m}^{-2} \mathrm{~d}^{-1}\right)$ of air-water gas exchange $\left(F_{\mathrm{AW}}\right)$, atmospheric degradation $\left(F_{\text {deg }}\right)$, dry deposition $\left(F_{\mathrm{DD}}\right)$, and wet deposition $\left(F_{\mathrm{WD}}\right)$ for individual PAHs during the ablation period and frozen periods.

\begin{tabular}{|c|c|c|c|c|c|c|c|c|}
\hline \multirow[t]{2}{*}{ PAH } & \multicolumn{4}{|c|}{ Ablation period } & \multirow[t]{2}{*}{ PAH } & \multicolumn{3}{|c|}{ Frozen period } \\
\hline & $F_{\mathrm{AW}}$ & $F_{\mathrm{deg}}$ & $F_{\mathrm{DD}}$ & $F_{\mathrm{WD}}$ & & $F_{\text {deg }}$ & $F_{\mathrm{DD}}$ & $F_{\mathrm{WD}}$ \\
\hline \multicolumn{9}{|c|}{ Volatilization compounds } \\
\hline Acel & $80 \pm 49$ & $6 \pm 5$ & NA & $-0.2 \pm 0.1$ & Acel & $1 \pm 0.7$ & $-0.02 \pm 0.001$ & $-0.03 \pm 0.1$ \\
\hline Ace & $51 \pm 19$ & $4 \pm 4$ & $-0.003 \pm 0.002$ & $-0.4 \pm 0.3$ & Ace & $0.9 \pm 0.5$ & $-0.01 \pm 0.01$ & $-6 \pm 5$ \\
\hline Flu & $203 \pm 162$ & $11 \pm 8$ & $-0.1 \pm 0.02$ & $-9 \pm 7$ & Flu & $1.8 \pm 0.9$ & $-0.2 \pm 0.2$ & $-43 \pm 30$ \\
\hline sum & 335 & 21 & -0.1 & -9 & sum & 4 & -0.2 & -49 \\
\hline Phe & $-340 \pm 604$ & $82 \pm 67$ & $-0.5 \pm 0.1$ & $-42 \pm 35$ & Phe & $10 \pm 4$ & $-2.2 \pm 1.2$ & $-345 \pm 237$ \\
\hline Ant & NA & $60 \pm 63$ & $-0.04 \pm 0.03$ & $-5 \pm 5$ & Ant & $4 \pm 2$ & $-0.11 \pm 0.05$ & $-16 \pm 14$ \\
\hline Fla & NA & $5 \pm 5$ & $-0.5 \pm 0.1$ & $-20 \pm 18$ & Fla & $0.5 \pm 0.3$ & $-4.6 \pm 2.8$ & $-93 \pm 64$ \\
\hline \multicolumn{9}{|c|}{ Deposition compounds } \\
\hline Pyr & $-145 \pm 154$ & $20 \pm 21$ & $-0.4 \pm 0.1$ & $-18 \pm 17$ & Pyr & $2 \pm 1$ & $-3 \pm 1.5$ & $-128 \pm 83$ \\
\hline $\mathrm{BaA}$ & $-19 \pm 23$ & NA & $-0.1 \pm 0.1$ & $-3 \pm 4$ & $\mathrm{BaA}$ & NA & $-1.1 \pm 0.5$ & $-15 \pm 10$ \\
\hline $\mathrm{Chr}$ & $-54 \pm 62$ & $7 \pm 8$ & $-0.5 \pm 0.3$ & $-47 \pm 56$ & $\mathrm{Chr}$ & $0.2 \pm 0.1$ & $-4.7 \pm 2.3$ & $-19 \pm 13$ \\
\hline Bbf & $-5 \pm 3$ & $0.2 \pm 0.1$ & $-0.6 \pm 0.5$ & $-6 \pm 5$ & $\mathrm{Bbf}$ & $0.02 \pm 0.01$ & $-2.2 \pm 3.2$ & $-4 \pm 8$ \\
\hline Bkf & $-2 \pm 1$ & $0.2 \pm 0.1$ & $-0.4 \pm 0.4$ & $-2 \pm 1$ & $\mathrm{Bkf}$ & $0.1 \pm 0.04$ & $-3.8 \pm 1.9$ & $-8 \pm 5$ \\
\hline Bap & $-2 \pm 1$ & $0.2 \pm 0.2$ & $-0.3 \pm 0.5$ & $-3 \pm 1$ & Bap & $0.04 \pm 0.03$ & $-4.7 \pm 2.3$ & $-16 \pm 10$ \\
\hline IcdP & $-2 \pm 1$ & $0.7 \pm 0.5$ & NA & $-2 \pm 2$ & IcdP & $0.1 \pm 0.1$ & NA & $-3 \pm 6$ \\
\hline DahA & $-1 \pm 0.7$ & $0.1 \pm 0.1$ & NA & $-0.1 \pm 0.2$ & DahA & $0.01 \pm 0.01$ & NA & $-0.6 \pm 1$ \\
\hline BghiP & $-2 \pm 0.4$ & $0.02 \pm 0.01$ & $-1 \pm 1$ & $-3 \pm 1$ & BghiP & $0.01 \pm 0.01$ & $-12 \pm 6$ & $-6 \pm 3$ \\
\hline sum & -231 & 28 & -3 & -85 & sum & 2 & -31 & -199 \\
\hline Total PAHs & 1 & 196 & -4.5 & -161 & Total PAHs & 20 & -38 & -702 \\
\hline
\end{tabular}

NA: not available. For $F_{\mathrm{AW}}, F_{\mathrm{DD}}$ and $F_{\mathrm{WD}}$, positive values indicate volatilization, and negative values indicate net deposition.

which will drive much larger depositional fluxes into the lake.

\subsubsection{Uncertainties in flux estimation}

Several factors were involved in the uncertainties of the flux estimation: (i) loss during sample extraction and clean-up, (ii) measurement errors, and (iii) accuracy of the parameters in meteorology and physicochemical properties. The airwater gas exchange flux $\left(F_{\mathrm{AW}}\right)$ is the most important contributor to the total inventory of PAHs in the lake. The uncertainty involved in $F_{\mathrm{AW}}$ was estimated by propagating the errors in $C_{\mathrm{a}}(30 \%), C_{\mathrm{w}}(35 \%), K_{\mathrm{ol}}(40 \%)$, and $H(20 \%)$, which was $64 \%$. This small error demonstrates that the estimate of the gas exchange fluxes was relatively robust. By contrast, the uncertainties in other fluxes were higher. The uncertainty of $F_{\mathrm{DD}}$ was estimated as a factor of 3 (GonzalezGaya et al., 2014). However, the uncertainties of $F_{\text {deg }}$ and $F_{\text {WD }}$ are difficult to quantify due to unavailable data on the relative errors of $K_{\mathrm{OH}}, W_{\mathrm{G}}$, and $W_{\mathrm{P}}$. For example, the scavenging rates of PAHs by wet deposition were highly variable, which was caused by the complexity of the size distribution of aerosols, meteorological conditions, and the scavenging process (Jurado et al., 2005). Considering these aggregated uncertainties, the estimated total fluxes here are only expected to capture the order of magnitude for the different processes. In addition, other input processes into the lake, such as glacier meltwater, river run-off, and soil erosion may also occur in this study region, which will lead to an underestimation of the total input flux.

\subsection{Implication for the regional carbon cycling}

Lakes are increasingly recognized as an important component of the terrestrial carbon cycle (Tranvik et al., 2009). Nearly $50 \%$ of the area of Chinese lakes is located on the $\mathrm{TP}$, with general oligotrophic conditions and a total lake area of $>43000 \mathrm{~km}^{2}$ (Zhang et al., 2014). Compared with other components, such as grassland and forest, organic carbon burial in Tibetan lakes has been largely ignored. Although our study only focused on one of these lakes (Nam Co, area $=2015 \mathrm{~km}^{2}$ ), we can extrapolate the annual atmospheric deposition of $\sum_{15}$ PAHs into the remaining Tibetan lakes, and estimate it at $8.7 \mathrm{t} \mathrm{C}$, when expressed as carbon fluxes (Gonzalez-Gaya et al., 2016). In addition to these 15 PAHs, there are other carbon sources such as soot, DOC, PAH derivatives, and other anthropogenic organic compounds, which would become a significant allochthonous carbon source for the oligotrophic lakes in TP. Because the Tibetan lakes are low in nutrients, bacteria in the lake have adapted 
to using a wide range of organic compounds and growing under starvation conditions (Liu et al., 2009). Recently, bacteria from the genus Sphingomonas were detected in Nam Co lake water and snow on various glaciers in the TP (Liu et al., 2009, 2013), and they were reported to have the ability to degrade PAHs (Leys et al., 2005). The presence of these bacteria in Nam Co suggests that the atmospheric inputs of organic pollutants can act as a carbon source to support the survival of Tibetan microbial communities. Despite the natural PAH background in the environment, increased biomass burning has led to the accumulation of PAHs in the lake sediments, especially during the past 50 years (Yang et al., 2016). Therefore, the continuous atmospheric deposition of various PAHs and their ecological impact deserve greater attention.

\section{Conclusions}

This study confirmed that the Nam Co lake was still a net sink of HCHs, following the LRAT-deposition process, rather than a secondary source. By contrast, PAHs primarily originated from local biomass burning. Dominated by gas exchange and wet deposition, the air-water fluxes of $\sum_{15}$ PAHs to the whole of the Nam Co lake were estimated to be $550 \mathrm{~kg} \mathrm{yr}^{-1}$, providing a substantial carbon source for the oligotrophic lake. Among the PAH compounds, Phe showed distinct behaviour with monthly reversals of the air-water exchange, which was most likely driven by the seasonal melting of lake ice. This hypothesis requires further investigation, and a passive sampling technique is recommended as a viable alternative to enhance the spatial coverage of the investigation of air-water exchange in the TP.

\section{The Supplement related to this article is available online at doi:10.5194/acp-17-1401-2017-supplement.}

Competing interests. The authors declare that they have no conflict of interest.

Acknowledgements. This study was supported by the National Natural Science Foundation of China (41671480, 41222010 and 41571463) and Youth Innovation Promotion Association (CAS2011067). The authors would like to thank the staff at Nam Co Monitoring and Research Station for Multisphere Interactions for their help with the field sampling.

Edited by: R. Ebinghaus

Reviewed by: T. Bidleman and one anonymous referee

\section{References}

Baek, S. Y., Choi, S. D., and Chang, Y. S.: Three-Year Atmospheric Monitoring of Organochlorine Pesticides and Polychlorinated Biphenyls in Polar Regions and the South Pacific, Environ. Sci. Technol., 45, 4475-4482, doi:10.1021/Es1042996, 2011.

Bailey, R. E.: Global hexachlorobenzene emissions, Chemosphere, 43, 167-182, doi:10.1016/S0045-6535(00)00186-7, 2001.

Bidleman, T. F., Jantunen, L. M., Kurt-Karakus, P. B., and Wong, F.: Chiral persistent organic pollutants as tracers of atmospheric sources and fate: review and prospects for investigating climate change influences, Atmos. Pollut. Res., 3, 371-382, doi:10.5094/Apr.2012.043, 2012.

Brubaker, W. W. and Hites, R. A.: OH Reaction Kinetics of GasPhase $\alpha$ - and $\gamma$-Hexachlorocyclohexane and Hexachlorobenzene, Environ. Sci. Technol., 32, 766-769, 1998.

Carrera, G., Fernández, P., Grimalt, J. O., Ventura, M., Camarero, L., Catalan, J., Nickus, U., Thies, H., and Psenner, R.: Atmospherc deposition of organochlorine compounds to remote high mountain lakes of Europe, Environ. Sci. Technol., 36, 25812588, 2002.

Cetin, B., Ozer, S., Sofuoglu, A., and Odabasi, M.: Determination of Henry's law constants of organochlorine pesticides in deionized and saline water as a function of temperature, Atmos. Environ., 40, 4538-4546, doi:10.1016/j.atmosenv.2006.04.009, 2006.

Chakraborty, P., Zhang, G., Li, J., Sivakumar, A., and Jones, K. C.: Occurrence and sources of selected organochlorine pesticides in the soil of seven major Indian cities: Assessment of air-soil exchange, Environ. Pollut., 204, 74-80, 2015.

Dalla Valle, M., Jurado, E., Dachs, J., Sweetman, A. J., and Jones, K. C.: The maximum reservoir capacity of soils for persistent organic pollutants: implications for global cycling, Environ. Pollut., 134, 153-164, doi:10.1016/j.envpol.2004.07.011, 2005.

Daly, G. L., Lei, Y. D., Teixeira, C., Muir, D. C. G., and Wania, F.: Pesticides in western Canadian mountain air and soil, Environ. Sci. Technol., 41, 6020-6025, doi:10.1021/Es070848o, 2007.

Ding, X., Wang, X. M., Xie, Z. Q., Xiang, C. H., Mai, B. X., Sun, L. G., Zheng, M., Sheng, G. Y., Fu, J. M., and Poschl, U.: Atmospheric polycyclic aromatic hydrocarbons observed over the North Pacific Ocean and the Arctic area: Spatial distribution and source identification, Atmos. Environ., 41, 2061-2072, doi:10.1016/j.atmonsenv.2006.11.002, 2007.

Fernandez, P., Grimalt, J. O., and Vilanova, R. M.: Atmospheric gas-particle partitioning of polycyclic aromatic hydrocarbons in high mountain regions of Europe, Environ. Sci. Technol., 36, 1162-1168, doi:10.1021/Es010190t, 2002.

Franz, T. P. and Eisenreich, S. J.: Snow scavenging of polychlorinated biphenyls and polycyclic aromatic hydrocarbons in Minnesota, Environ. Sci. Technol., 32, 1771-1778, doi:10.1021/Es970601z, 1998.

Froescheis, O., Looser, R., Cailliet, G. M., Jarman, W. M., and Ballschmiter, K.: The deep-sea as a final global sink of semivolatile persistent organic pollutants? Part I: PCBs in surface and deep-sea dwelling fish of the North and South Atlantic and the Monterey Bay Canyon (California), Chemosphere, 40, 651-660, doi:10.1016/S0045-6535(99)00461-0, 2000.

Geisz, H. N., Dickhut, R. M., Cochran, M. A., Fraser, W. R., and Ducklow, H. W.: Melting glaciers: A probable source of DDT to the Antarctic marine ecosystem, Environ. Sci. Technol., 42, 3958-3962, doi:10.1021/es702919n, 2008. 
Gioia, R., Lohmann, R., Dachs, J., Temme, C., Lakaschus, S., Schulz-Bull, D., Hand, I., and Jones, K. C.: Polychlorinated biphenyls in air and water of the North Atlantic and Arctic Ocean, J. Geophys. Res., 113, D19302, doi:10.1029/2007jd009750, 2008.

Gioia, R., Li, J., Schuster, J., Zhang, Y. L., Zhang, G., Li, X. D., Spiro, B., Bhatia, R. S., Dachs, J., and Jones, K. C.: Factors Affecting the Occurrence and Transport of Atmospheric Organochlorines in the China Sea and the Northern Indian and South East Atlantic Oceans, Environ. Sci. Technol., 46, 1001210021, doi:10.1021/Es302037t, 2012.

Gong, P., Wang, X. P., and Yao, T. D.: Ambient distribution of particulate- and gas-phase n-alkanes and polycyclic aromatic hydrocarbons in the Tibetan Plateau, Environ. Earth Sci., 64, 17031711, doi:10.1007/s12665-011-0974-3, 2011.

Gonzalez-Gaya, B., Zuniga-Rival, J., Ojeda, M. J., Jimenez, B., and Dachs, J.: Field Measurements of the Atmospheric Dry Deposition Fluxes and Velocities of Polycyclic Aromatic Hydrocarbons to the Global Oceans, Environ. Sci. Technol., 48, 5583-5592, doi:10.1021/es500846p, 2014.

Gonzalez-Gaya, B., Fernandez-Pinos, M. C., Morales, L., Mejanelle, L., Abad, E., Pina, B., Duarte, C. M., Jimenez, B., and Dachs, J.: High atmosphere-ocean exchange of semivolatile aromatic hydrocarbons, Nat. Geosci., 9, 438-442, doi:10.1038/NGEO2714, 2016.

Guglielmo, F., Stemmler, I., and Lammel, G.: The impact of organochlorines cycling in the cryosphere on their global distribution and fate-1, Sea ice, Environ. Pollut., 162, 475-481, doi:10.1016/j.envpol.2011.09.039, 2012.

Guzzella, L., Poma, G., De Paolis, A., Roscioli, C., and Viviano, G.: Organic persistent toxic substances in soils, waters and sediments along an altitudinal gradient at Mt. Sagarmatha, Himalayas, Nepal, Environ. Pollut., 159, 2552-2564, doi:10.1016/j.envpol.2011.06.015, 2011.

Harner, T., Wiberg, K., and Norstrom, R.: Enantiomer fractions are preferred to enantiomer ratios for describing chiral signatures in environmental analysis, Environ. Sci. Technol., 34, 218-220, 2000.

Hu, T., Cao, J., Lee, S., Ho, K., Li, X., Liu, S., and Chen, J.: Physiochemical characteristics of indoor $\mathrm{PM}_{2.5}$ with combustion of dried yak dung as biofuel in Tibetan Plateau, China, Indoor Built Environ, 191, 172-181, 2015.

Huang, Y. M., Xu, Y., Li, J., Xu, W. H., Zhang, G., Cheng, Z. N., Liu, J. W., Wang, Y., and Tian, C. G.: Organochlorine Pesticides in the Atmosphere and Surface Water from the Equatorial Indian Ocean: Enantiomeric Signatures, Sources, and Fate, Environ. Sci. Technol., 47, 13395-13403, doi:10.1021/Es403138p, 2013.

Hung, H., Kallenborn, R., Breivik, K., Su, Y. S., Brorstrom-Lunden, E., Olafsdottir, K., Thorlacius, J. M., Leppanen, S., Bossi, R., Skov, H., Mano, S., Patton, G. W., Stern, G., Sverko, E., and Fellin, P.: Atmospheric monitoring of organic pollutants in the Arctic under the Arctic Monitoring and Assessment Programme (AMAP): 1993-2006, Sci. Total Environ., 408, 2854-2873, doi:10.1016/j.scitotenv.2009.10.044, 2010.

Iwata, H., Tanabe, S., Sakal, N., and Tatsukawa, R.: Distribution of Persistent Organochlorines in the Oceanic Air and Surface Seawater and the Role of Ocean on Their Global Transport and Fate, Environ. Sci. Technol., 27, 1080-1098, 1993.
Jantunen, L. M., Helm, P. A., Kylin, H., and Bidlemant, T. F.: Hexachlorocyclohexanes (HCHs) in the Canadian archipelago, 2. Air-water gas exchange of alpha- and gamma-HCH, Environ. Sci. Technol., 42, 465-470, doi:10.1021/Es071646v, 2008.

Jantunen, L. M., Wong, F., Gawor, A., Kylin, H., Helm, P. A., Stern, G. A., Strachan, W. M. J., Burniston, D. A., and Bidleman, T. F.: 20 Years of Air-Water Gas Exchange Observations for Pesticides in the Western Arctic Ocean, Environ. Sci. Technol., 49, 1384413852, doi:10.1021/acs.est.5b01303, 2015.

Jurado, E., Jaward, F., Lohmann, R., Jones, K. C., Simo, R., and Dachs, J.: Wet deposition of persistent organic pollutants to the global oceans, Environ. Sci. Technol., 39, 2426-2435, doi:10.1021/Es048599g, 2005.

Kang, J. H., Choi, S. D., Park, H., Baek, S. Y., Hong, S., and Chang, Y. S.: Atmospheric deposition of persistent organic pollutants to the East Rongbuk Glacier in the Himalayas, Sci. Total Environ., 408, 57-63, doi:10.1016/j.scitotenv.2009.09.015, 2009.

Keyte, I. J., Harrison, R. M., and Lammel, G.: Chemical reactivity and long-range transport potential of polycyclic aromatic hydrocarbons - a review, Chem. Soc. Rev., 42, 9333-9391, doi:10.1039/c3cs60147a, 2013.

Khairy, M., Muir, D., Teixeira, C., and Lohmann, R.: Spatial Trends, Sources, and Air-Water Exchange of Organochlorine Pesticides in the Great Lakes Basin Using Low Density Polyethylene Passive Samplers, Environ. Sci. Technol., 48, 9315-9324, doi:10.1021/es501686a, 2014.

Komprda, J., Komprdova, K., Sanka, M., Mozny, M., and Nizzetto, L.: Influence of Climate and Land Use Change on Spatially Resolved Volatilization of Persistent Organic Pollutants (POPs) from Background Soils, Environ. Sci. Technol., 47, 7052-7059, doi:10.1021/es30437134, 2013.

Kurt-Karakus, P. B., Bidleman, T. F., Staebler, R. M., and Jones, K. C.: Measurement of DDT fluxes from a historically treated agricultural soil in Canada, Environ. Sci. Technol., 40, 4578-4585, doi:10.1021/Es060216m, 2006.

Law, S. A., Diamond, M. L., Helm, P. A., Jantunen, L. M., and Alaee, M.: Factors affecting the occurrence and enantiomeric degradation of hexachlorocyclohexane isomers in northern and temperate aquatic systems, Environ. Toxicol. Chem., 20, 26902698, 2001.

Leys, N. M., Ryngaert, A., Bastiaens, L., Top, E. M., Verstraete, W., and Springael, D.: Culture Independent Detection of Sphingomonas sp. EPA 505 Related Strains in Soils Contaminated with Polycyclic Aromatic Hydrocarbons (PAHs), Microb. Ecol., 49, 443-450, 2005.

Li, C. L., Kang, S. C., Chen, P. F., Zhang, Q. G., and Fang, G. C.: Characterizations of particle-bound trace metals and polycyclic aromatic hydrocarbons (PAHs) within Tibetan tents of south Tibetan Plateau, China, Environ. Sci. Pollut. Res., 19, 1620-1628, doi:10.1007/s11356-011-0678-y, 2012.

Li, C. L., Bosch, C., Kang, S. C., Andersson, A., Chen, P. F., Zhang, Q. G., Cong, Z. Y., Chen, B., Qin, D. H., and Gustafsson, O.: Sources of black carbon to the Himalayan-Tibetan Plateau glaciers, Nat. Commun., 7, 12574, doi:10.1038/Ncomms12574, 2016.

Li, J., Zhu, T., Wang, F., Qiu, X. H., and Lin, W. L.: Observation of organochlorine pesticides in the air of the Mt. Everest region, Ecotoxicol. Environ. Saf., 63, 33-41, doi:10.1016/j.ecoenv.2005.04.001, 2006. 
Liu, X. and Chen, B.: Climatic warming in the Tibetan Plateau during recent decades, Int. J. Climatol., 20, 1729-1742, 2000.

Liu, X. B., Yao, T. D., Kang, S. C., Jiao, N. A. Z., Zeng, Y. H., and Liu, Y. Q.: Bacterial Community of the Largest Oligosaline Lake, Namco on the Tibetan Plateau, Geomicrobiol. J., 27, 669682, doi:10.1080/01490450903528000, 2010.

Liu, Y. Q., Yao, T. D., Jiao, N. Z., Kang, S. C., Xu, B. Q., Zeng, Y. H., Huang, S. J., and Liu, X. B.: Bacterial diversity in the snow over Tibetan Plateau Glaciers, Extremophiles, 13, 411423, doi:10.1007/s00792-009-0227-5, 2009.

Liu, Y. Q., Yao, T. D., Jiao, N. Z., Liu, X. B., Kang, S. C., and Luo, T. W.: Seasonal Dynamics of the Bacterial Community in Lake Namco, the Largest Tibetan Lake, Geomicrobiol. J., 30, 17-28, doi:10.1080/01490451.2011.638700, 2013.

Lohmann, R., Gioia, R., Jones, K. C., Nizzetto, L., Temme, C., Xie, Z., Schulz-Bull, D., Hand, I., Morgan, E., and Jantunen, L.: Organochlorine Pesticides and PAHs in the Surface Water and Atmosphere of the North Atlantic and Arctic Ocean, Environ. Sci. Technol., 43, 5633-5639, doi:10.1021/Es901229k, 2009.

Ma, J. M., Hung, H. L., Tian, C., and Kallenborn, R.: Revolatilization of persistent organic pollutants in the Arctic induced by climate change, Nature Climate Change, 1, 255-260, doi:10.1038/Nclimate1167, 2011.

Ma, Y. G., Lei, Y. D., Xiao, H., Wania, F., and Wang, W. H.: Critical Review and Recommended Values for the PhysicalChemical Property Data of 15 Polycyclic Aromatic Hydrocarbons at $25^{\circ} \mathrm{C}$, J. Chem. Eng. Data., 55, 819-825, doi:10.1021/Je900477x, 2010.

Ma, Y. X., Xie, Z. Y., Yang, H. Z., Moller, A., Halsall, C., Cai, M. H., Sturm, R., and Ebinghaus, R.: Deposition of polycyclic aromatic hydrocarbons in the North Pacific and the Arctic, J. Geophys. Res., 118, 5822-5829, doi:10.1002/jgrd.50473, 2013.

Mulder, M. D., Heil, A., Kukucka, P., Klanova, J., Kuta, J., Prokes, R., Sprovieri, F., and Lammel, G.: Air-sea exchange and gas-particle partitioning of polycyclic aromatic hydrocarbons in the Mediterranean, Atmos. Chem. Phys., 14, 8905-8915, doi:10.5194/acp-14-8905-2014, 2014.

Nizzetto, L., Lohmann, R., Gioia, R., Jahnke, A., Temme, C., Dachs, J., Herckes, P., Di, G. A., and Jones, K. C.: PAHs in air and seawater along a North-South Atlantic transect: trends, processes and possible sources, Environ. Sci. Technol., 42, 15801585, 2008.

Noyes, P. D., McElwee, M. K., Miller, H. D., Clark, B. W., Van Tiem, L. A., Walcott, K. C., Erwin, K. N., and Levin, E. D.: The toxicology of climate change: Environmental contaminants in a warming world, Environ. Int., 35, 971-986, doi:10.1016/j.envint.2009.02.006, 2009.

Ridal, J. J., Bidleman, T. F., Kerman, B. R., Fox, M. E., and Strachan, W. M. J.: Enantiomers of alpha-hexachlorocyclohexane as tracers of air-water gas exchange in Lake Ontario, Environ. Sci. Technol., 31, 1940-1945, doi:10.1021/Es9607244, 1997.

Ruzickova, P., Klanova, J., Cupr, P., Lammel, G., and Holoubek, I.: An assessment of air-soil exchange of polychlorinated biphenyls and organochlorine pesticides across Central and Southern Europe, Environ. Sci. Technol., 42, 179-185, doi:10.1021/Es071406f, 2008.

Sheng, J. J., Wang, X. P., Gong, P., Joswiak, D. R., Tian, L. D., Yao, T. D., and Jones, K. C.: Monsoon-driven transport of organochlorine pesticides and polychlorinated biphenyls to the tibetan plateau: three year atmospheric monitoring study, Environ. Sci. Technol., 47, 3199-3208, doi:10.1021/es305201s, 2013.

Spivakovsky, C. M., Logan, J. A., Montzka, S. A., Balkanski, Y. J., Foreman-Fowler, M., Jones, D. B. A., Horowitz, L. W., Fusco, A. C., Brenninkmeijer, C. A. M., and Prather, M. J.: Threedimensional climatological distribution of tropospheric $\mathrm{OH}$ : Update and evaluation, J. Geophys. Res., 105, 8931-8980, 2000.

Stemmler, I. and Lammel, G.: Cycling of DDT in the global environment 1950-2002: World ocean returns the pollutant, Geophys. Res. Lett., 36, L24602, doi:10.1029/2009GL041340, 2009.

Su, Y. S., Hung, H., Blanchard, P., Patton, G. W., Kallenborn, R., Konoplev, A., Fellin, P., Li, H., Geen, C., Stern, G., Rosenberg, B., and Barrie, L. A.: Spatial and seasonal variations of hexachlorocyclohexanes (HCHs) and hexachlorobenzene (HCB) in the Arctic atmosphere, Environ. Sci. Technol., 40, 6601-6607, doi:10.1021/Es061065q, 2006.

Su, Y. S., Hung, H., Blanchard, P., Patton, G. W., Kallenborn, R., Konoplev, A., Fellin, P., Li, H., Geen, C., Stern, G., Rosenberg, B., and Barrie, L. A.: A circumpolar perspective of atmospheric organochlorine pesticides (OCPs): Results from six Arctic monitoring stations in 2000-2003, Atmos. Environ., 42, 4682-4698, doi:10.1016/j.atmosenv.2008.01.054, 2008.

Tranvik, L. J., Downing, J. A., Cotner, J. B., Loiselle, S. A., Striegl, R. G., Ballatore, T. J., Dillon, P., Finlay, K., Fortino, K., Knoll, L. B., Kortelainen, P. L., Kutser, T., Larsen, S., Laurion, I., Leech, D. M., McCallister, S. L., McKnight, D. M., Melack, J. M., Overholt, E., Porter, J. A., Prairie, Y., Renwick, W. H., Roland, F., Sherman, B. S., Schindler, D. W., Sobek, S., Tremblay, A., Vanni, M. J., Verschoor, A. M., von Wachenfeldt, E., and Weyhenmeyer, G. A.: Lakes and reservoirs as regulators of carbon cycling and climate, Limnol. Oceanogr., 54, 2298-2314, doi:10.4319/lo.2009.54.6_part_2.2298, 2009.

Tremolada, P., Villa, S., Bazzarin, P., Bizzotto, E., Comolli, R., and Vighi, M.: POPs in Mountain Soils from the Alps and Andes: Suggestions for a "Precipitation Effect" on Altitudinal Gradients, Water Air Soil Pollut., 188, 93-109, 2008.

Venier, M., Dove, A., Romanak, K., Backus, S., and Hites, R.: Flame Retardants and Legacy Chemicals in Great Lakes' Water, Environ. Sci. Technol., 48, 9563-9572, doi:10.1021/es501509r, 2014.

Vilanova, R. M., Fernandez, P., Martinez, C., and Grimalt, J. O.: Polycyclic aromatic hydrocarbons in remote mountain lake waters, Water Res., 35, 3916-3926, doi:10.1016/S00431354(01)00113-0, 2001.

Wang, C. F., Wang, X. P., Gong, P., and Yao, T. D.: Polycyclic aromatic hydrocarbons in surface soil across the Tibetan Plateau: Spatial distribution, source and air-soil exchange, Environ. Pollut., 184, 138-144, doi:10.1016/j.envpol.2013.08.029, 2014.

Wang, J. B., Zhu, L. P., Daut, G., Ju, J. T., Lin, X., Wang, Y., and Zhen, X. L.: Investigation of bathymetry and water quality of Lake Nam Co, the largest lake on the central Tibetan Plateau, China, Limnology, 10, 149-158, doi:10.1007/s10201-009-02668, 2009.

Wang, X. P., Sheng, J. J., Gong, P., Xue, Y. G., Yao, T. D., and Jones, K. C.: Persistent organic pollutants in the Tibetan surface soil: Spatial distribution, air-soil exchange and implications for global cycling, Environ. Pollut., 170, 145-151, doi:10.1016/j.envpol.2012.06.012, 2012. 
Wang, X. P., Gong, P., Sheng, J. J., Joswiak, D. R., and Yao, T. D.: Long-range atmospheric transport of particulate Polycyclic Aromatic Hydrocarbons and the incursion of aerosols to the southeast Tibetan Plateau, Atmos. Environ., 115, 124-131, doi:10.1016/j.atmosenv.2015.04.050, 2015.

Wang, X. P., Gong, P., Wang, C. F., Ren, J., and Yao, T. D.: A review of current knowledge and future prospects regarding persistent organic pollutants over the Tibetan Plateau, Sci. Total Environ., 573, 139-154, doi:10.1016/j.scitotenv.2016.08.107, 2016.

Wania, F., Axelman, J., and Broman, D.: A review of processes involved in the exchange of persistent organic pollutants across the air-sea interface, Environ. Pollut., 102, 3-23, doi:10.1016/S0269-7491(98)00072-4, 1998a.

Wania, F., Haugen, J. E., Lei, Y. D., and Mackay, D.: Temperature dependence of atmospheric concentrations of semivolatile organic compounds, Environ. Sci. Technol., 32, 1013-1021, doi:10.1021/Es970856c, 1998b.

Wania, F., Hoff, J. T., Jia, C. Q., and Mackay, D.: The effects of snow and ice on the environmental behaviour of hydrophobic organic chemicals, Environ. Pollut., 102, 25-41, doi:10.1016/S0269-7491(98)00073-6, 1998c.

Wilkinson, A. C., Kimpe, L. E., and Blais, J. M.: Air-water gas exchange of chlorinated pesticides in four lakes spanning a 1,205 meter elevation range in the Canadian Rocky Mountains, Environ. Toxicol. Chem., 24, 61-69, doi:10.1897/04-071r.1, 2005.

Wong, F., Jantunen, L. M., Pucko, M., Papakyriakou, T., Staebler, R. M., Stern, G. A., and Bidleman, T. F.: Air-Water Exchange of Anthropogenic and Natural Organohalogens on International Polar Year (IPY) Expeditions in the Canadian Arctic, Environ. Sci. Technol., 45, 876-881, doi:10.1021/Es1018509, 2011.
Wu, Y. H., Zheng, H. X., Zhang, B., Chen, D. M., and Lei, L. P.: Long-Term Changes of Lake Level and Water Budget in the Nam Co Lake Basin, Central Tibetan Plateau, J. Hydrometeorol., 15, 1312-1322, doi:10.1175/Jhm-D-13-093.1, 2014.

Xiao, H., Kang, S. C., Zhang, Q. G., Han, W. W., Loewen, M., Wong, F., Hung, H., Lei, Y. D., and Wania, F.: Transport of semivolatile organic compounds to the Tibetan Plateau: Monthly resolved air concentrations at Nam Co, J. Geophys. Res., 115, D16310, doi:10.1029/2010jd013972, 2010.

Xiao, Q. Y., Saikawa, E., Yokelson, R. J., Chen, P. F., Li, C. L., and Kang, S. C.: Indoor air pollution from burning yak dung as a household fuel in Tibet, Atmos. Environ., 102, 406-412, doi:10.1016/j.atmosenv.2014.11.060, 2015.

Yang, R. Q., Xie, T., An, L., Yang, H., Turner, S., Wu, G., and Jing, C.: Sedimentary records of polycyclic aromatic hydrocarbons (PAHs) in remote lakes across the Tibetan Plateau, Environ. Pollut., 214, 1-7, 2016.

Yao, T. D., Thompson, L. G., Mosbrugger, V., Zhang, F., Ma, Y., Luo, T., Xu, B. Q., Yang, X., Joswiak, D. R., Wang, W., Joswiak, M. E., Devkota, L. P., Tayal, S., Jilani, R., and Fayziev, R.: Third Pole Environment (TPE), Environ. Dev., 3, 52-64, doi:10.1016/j.envdev.2012.04.002, 2012.

Zhang, G., Chakraborty, P., Li, J., Sampathkumar, P., Balasubramanian, T., Kathiresan, K., Takahashi, S., Subramanian, A., Tanabe, S., and Jones, K. C.: Passive Atmospheric Sampling of Organochlorine Pesticides, Polychlorinated Biphenyls, and Polybrominated Diphenyl Ethers in Urban, Rural, and Wetland Sites along the Coastal Length of India, Environ. Sci. Technol., 42, 8218-8223, doi:10.1021/Es8016667, 2008.

Zhang, G. Q., Yao, T. D., Xie, H. J., Zhang, K. X., and Zhu, F. J.: Lakes' state and abundance across the Tibetan Plateau, Chin. Sci Bull., 59, 3010-3021, doi:10.1007/s11434-014-0258-x, 2014.

Zhang, W. L., Zhang, G., Qi, S. H., and Peng, P. A.: A preliminary study of organochlorinepesticides in water and sediments from two Tibetan Lakes, Geochimica, 32, 363-367, 2003 (in Chinese with English abstract). 